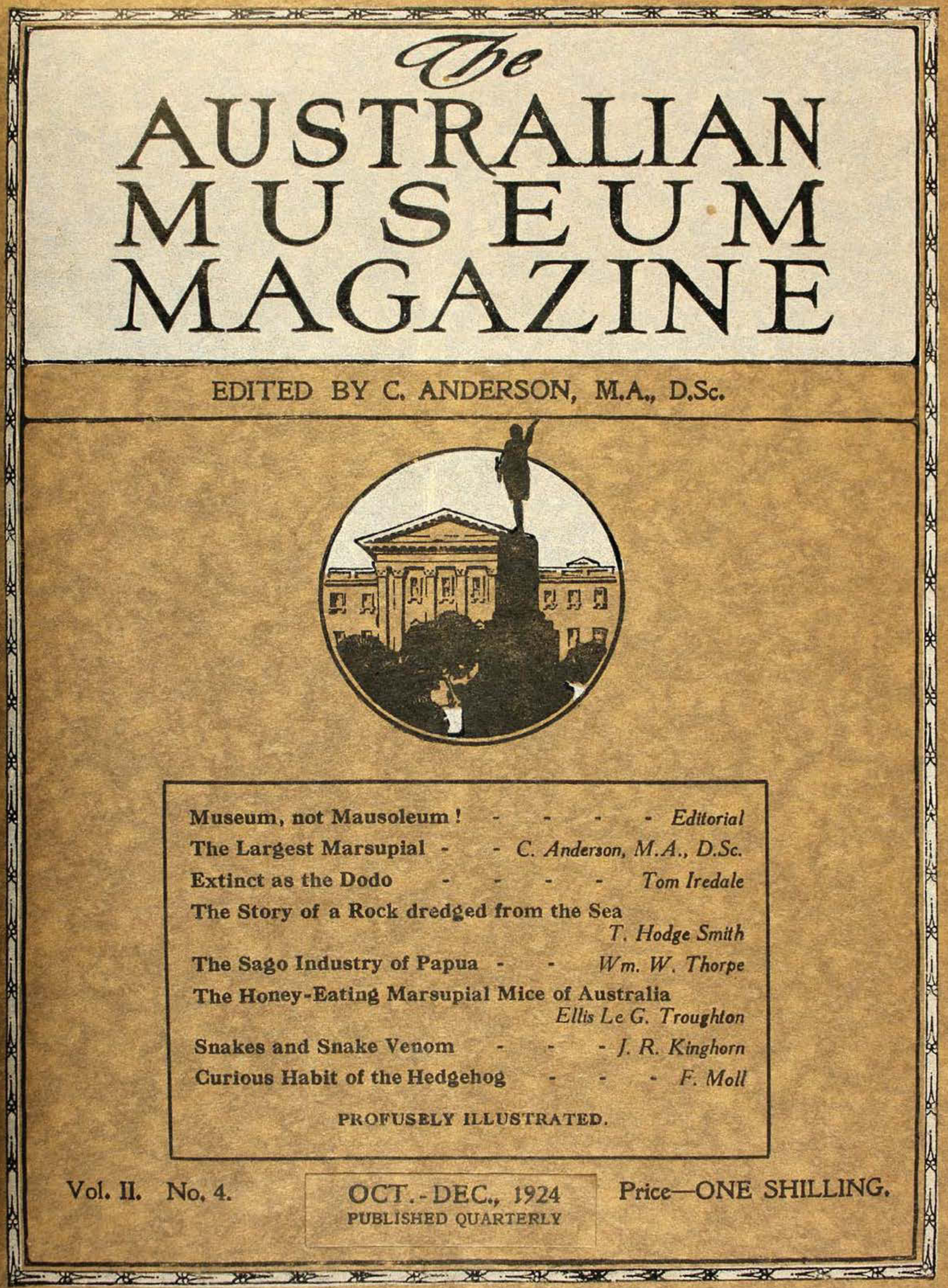




\title{
THE AUSTRALIAN MUSEUM
}

\section{COLLEGE STREET, SYDNEY.}

\section{BOARD OF TRUSTEES :}

President :

T. Storin Dixson, M.B., Ch.M., Knight of Grace of the Order of St. John.

\author{
Crown Trustee : \\ James MoKrerN. \\ Officlal Trustees:
}

His Honoun the Chiet Justick.

The hon. the President of thre Legislative Counctr.

Tho Hon. the Colontal Secristary.

The hon. the Attorney-General.

The Hon. the Coloniat Trkasurek.

The Hon. ghe Secretary jor Public Works and Minister for Ramifays. The Hon. the Ministibr of Publio Instruction.

The AUditor-GenisRaL.

The President of the N.S.Wales Mrdioal Bonte (T. Storir Dixson, M.B., Ch.M.). The Surveyor-Genrral and Chimf Surviyor.

The Crown Solicitor.

W. H, H HRGRAVES.

ERIC Sinchair, M.D.

J. R. M. ROBERTSON, M.D., C.M.

ERNRST WUNDERLICH, F.R.A.S.

G. H. Аввотт, B.A., M.B., Ch.M.

The Hon. D. Levix, LL.B., M.L.A.

J. J. Fletcher, M.A., B.Sc.
Elective Trustees :

Sir William Vicars, KT. Maj.-Gen. Sir Charles Rosenghat, K.C.B., C.M.G., D.S.O., V.D., M.L.A.

Prof. L. Harrison, B.A., B.So.

E. C. ANDREWS, B.A., F.G.S.

Octavius C. Beale.

Direetor :

Charlizs Anderson, M.A., D.Sc.

Seeretary :

W. T. WELIS, A.I.A.V.

Scientific Staff:

Allan R. MoCulloch, Zoologist, in charge of Fishes.

WHuAN W. THORPE, Ethnologist.

J. ROY KrNGHORN, Zoologist, in charge of Birds, Reptiles, and Amphibians.

Euris LE G. Trovghton, Zoologist, in charge of Mammals and Skeletons.

Anthony Musgraye, Entomologist.

F. A. MoNwIL, Zoologist, in charge of Lower Invertebrates.

T. Hodar SMrtH, Mineralogist and Petrologist.

Librarian :

W. A. Rannbow. 


\section{THE AUSTRALIAN MUSEUM MAGAZINE}

Vol. II., No. 4. CONTENTS OCt. DeC., 1924

The Sago Industry of Papua. Removing the Cortex of the SAgo Palm-Captain Frank

$\begin{array}{llllllll}\text { Hurley } & \ldots & \ldots & \ldots & \ldots & \ldots & \ldots & \ldots \text { Frontispiece }\end{array}$

Edtorial-Museum, not Mausoleum $\quad \ldots \quad \ldots l 11$

The Largest Marsupial-C. Anderson, M.A., D.Sc... 113

As Extinct as the Dodo-Tom Iredale $\quad \ldots \quad \ldots \quad 117$

The Story of a Rock Dredged from the Sea- $T$.

$\begin{array}{llllllll}\text { Hodge Smith } & \ldots & \ldots & \ldots & \ldots & \ldots & \ldots & 121\end{array}$

The Sago Industry of Papua-Wm. W. Thorpe $\quad \ldots \quad 123$

The Honex-Eating Marsupial Mice of Australia-

$\begin{array}{lllllll}\text { Ellis Le G. Troughton ... } & \ldots & \ldots & \ldots & \ldots & 127\end{array}$

$\begin{array}{lllllll}\text { Notes and News } & \ldots & \ldots & \ldots & \ldots & \ldots & 132,138\end{array}$

Dinosaur Eggs - C. Anderson. M.A., D.Sc. $\quad \ldots \quad \ldots \quad \ldots 33$

Curious Habit of the Hedgehog-F. Moll $\ldots . \quad \ldots \quad 135$

Radium and the Age of the Earth-T. Hodge Smith 136

Fruit Bat Group-E. Le G. Troughton $\quad$.. $\quad \ldots \quad 140$

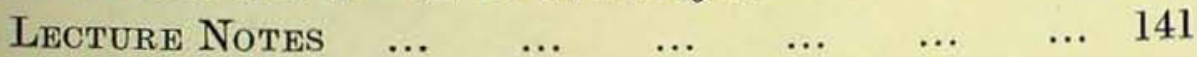

SNAKES AND SNAKE VENOM- J. R. Kinghorn $\ldots \quad \ldots \quad 142$

Published Quarterly by the Trustees of the Australian Museum, College Street, Sydney, in the months of January, April, July, and October. Subscription $4 / 4$, including postage.

Communications regarding subscriptions, advertising rates, and business matters generally in connection with THE A USTRALIAN MUSEUM MAGAZINE should be addressed to the Secretary. 


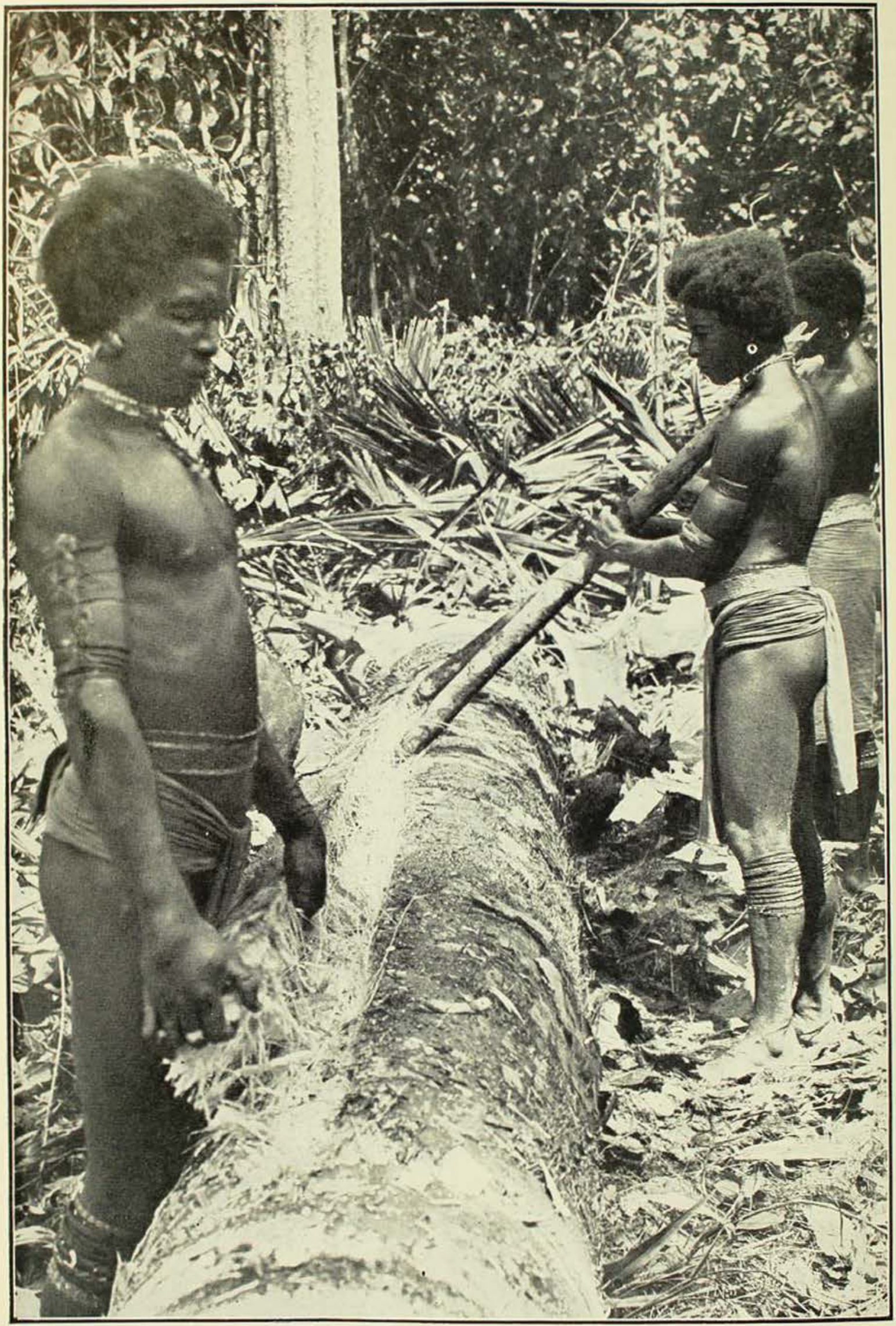

The Sago Industry of Papua. Removing the cortex, or outer rind, of the Sago Palm. Incisions are made along the trunk and the cortex is wedged and prised off. 


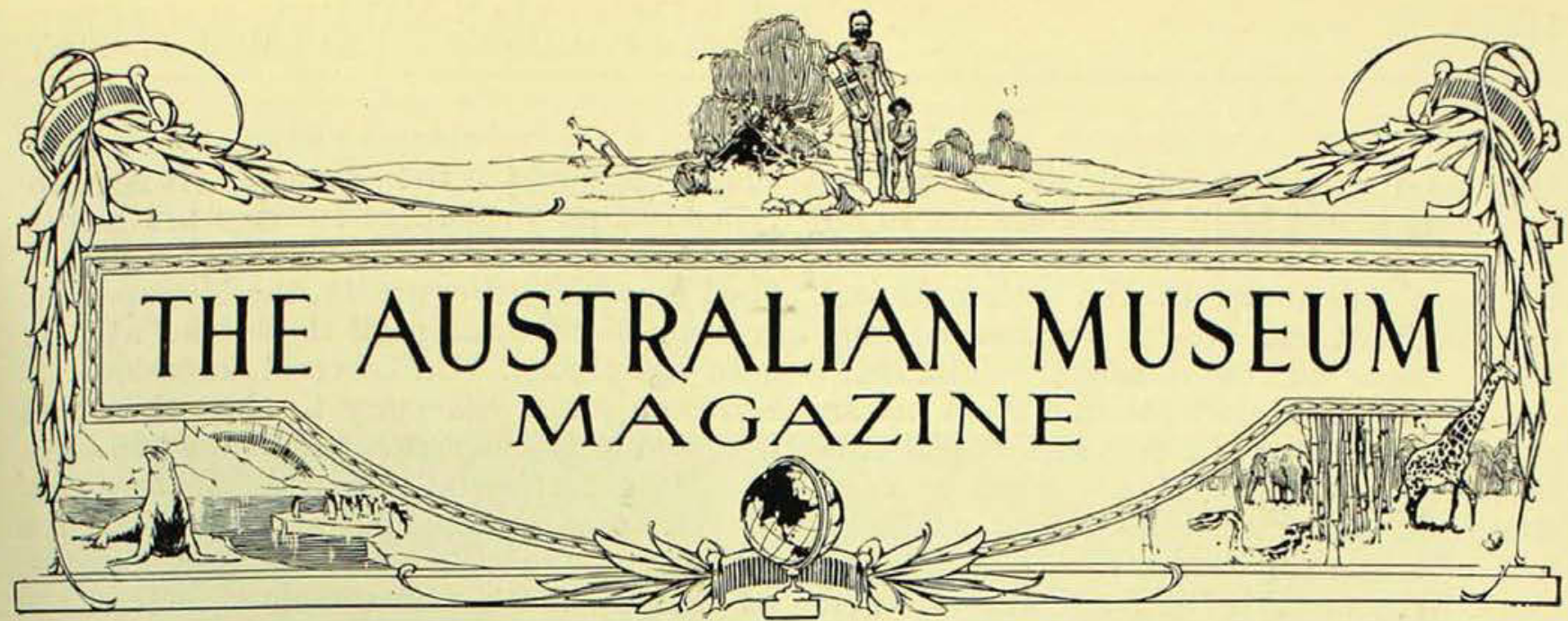

Published by the Australian Museum

College Street, Sydney

Editor: C. Anderson, M.A., D.Sc.

Annual Subscription, Post Free, 4/4.

VoL. II., No. 4.

OCtober-December, 1924

\section{Editorial}

\section{Museum, Not Mausoleum!}

$M^{N}$

ANY people still regard museums as places where mummies, stuffed animals, fossils, and such trifles are preserved for the curious to gape at. If they are right then it is doubtful whether States or municipalities would be justified in spending public money in maintaining museums.

In an article entitled " Scope and Work of the Australian Museum," which appeared in the first number of this Magazine, the following passage occurred: "Why should we wish to assemble and preserve these objects?" The answer is twofold. In the first place they form the subject matter on which present knowledge is based, and the material by use of which future workers may still further extend the bounds of knowledge. Secondly, when properly displayed they contribute to the wonder, pleasure, and instruction of the public. These sentences epitomise the whole aim and object of museums and museum work."

Knowledge is worth pursuing for its own sake, and certain kinds of knowledge are best obtained by the help of such institutions as the Australian Museum. Thus the in- vestigation of our fauna, past and present, the study of specific distributions, the variation of animals, their relation to man, to one another, to the plant world and the soil, can be pursued only by the aid of extensive, accurately determined, and well arranged collections. Such collections become as dictionaries to which all may refer for information, but these dictionaries can be compiled only by devoted and unremitting research. The " hard headed business man" may say, " but what is the use of it ? Why should money and time be expended in making these collections so that specialists may tack Latin and Greek names to bugs and other things ?" A little story related by Dr. F. A. Bather, the distinguished Keeper of Geology in the British Museum, and one of the foremost authorities on museology, may be of interest to such Gallios.

Some years ago the sugar crop of Mauritius was found to be suffering from the attacks of a beetle larva. The local Government Entomologist was called in to advise, and he determined it provisionally as a member of an African genus. But, fortunately, he 
forwarded some specimens to the British Museum for more accurate determination, and there it was found to belong, not to an African, but to an American genus. In the vast collections of the entomological department three similar specimens were found, unnamed, but labelled "Trinidad." Armed with this information, a West Indian entomologist searched for and found the beetle and its larva at the roots of cane stumps in Barbados. But it had not been found destructive to the West Indian cane crops. Why was this? Investigation showed that, as in so many cases, this beetle had certain natural enemies in its homeland, particularly a kind of wasp which paralysed the beetle larva to form a store of food for its young. By this means the pest was kept in check in the West Indies, but, when the beetle larva was accidentally introduced into Mauritius, it flourished exceedingly in the absence of its natural enemies. However, when the wasp too was introduced into Mauritius the ravages of the beetle were checked, and the future of the sugar crop assured.

Many similar cases could be quoted, but perhaps no finer example could be instanced to prove the economic value of museum collections. In this case the beetle belonged to an undescribed species, but the museum specimens were properly classified according to genus and family, so that rapid reference was possible. So much for that aspect of museum work, an aspect the importance of which is often overlooked.

The second object of museums is to interest and instruct the people. This is done by means of exhibits, by publications, technical and popular, by lectures and demonstrations. Of recent years the trustees and staff of the Australian Museum have strenuously endeavoured to extend its usefulness in this direction. The scientific publications of the Museum are well known not only in Australia, but abroad. This magazine was founded in order to supply reading matter of a more popular nature, scientifically accurate, but couched in simple, untechnical language, and attractively illustrated. Popular lectures were established years ago, and no effort has been spared to extend and improve them. A high standard has been attained both in the subject matter of the lectures and in the lantern slides and cinema pictures which play such a large part in their success. It is grati. fying to find that these lectures are highly appreciated, and that the attendance is so good that, not infrequently, the Museum hall is not able to contain all those who wish to gain admission. On several occasions it has been found necessary to close the doors long before the advertised hour, and to have the lecture repeated on a subsequent oc. casion. The trustees have also initiated a campaign of suburban and country lectures, so that those who are unable to attend the regular course may not be debarred from sharing the benefits of this side of the museum's activities.

This year lectures to school children have been instituted in co-operation with the Department of Education. This movement owes much to the enthusiasm and active interest of Chief-Inspector H. D. McLelland and Miss Margaret Deer of the Teachers' Training College. The subject matter of these lectures is specially chosen and illustrated, so that they may be both educational and interesting, the object being to arouse in the minds of the youthful hearers an appreciation of the wonders of nature and to train them to use the faculty of observation.

At the same time every effort has been made to improve the exhibits, particularly by the installation of groups, anthropological and zoological. Already five habitat groups are on exhibition, and another is nearing completion. A fine group, showing a Hawaiian family busy with their household tasks, has been on view for some time, and, by the liberality of one of our trustees, Mr. Ernest Wunderlich, F.R.A.S., we shall soon be able to show a group of Australian aboriginals. The New Guinea "Ravi," though not yet finished, is now open for public inspection, and few more impressive and instructive exhibits can be found in any museum. By such means the trustees hope to stimulate a livelier interest in the exhibits and to add to the educational value of the Museum.

We may surely claim that the Australian Museum is trying to fulfil its mission as well as funds and opportunities will permit. What is wanted is more funds and greater opportunities. 


\section{The Largest Marsupial.}

By C. Anderson, M.A., D.Sc.

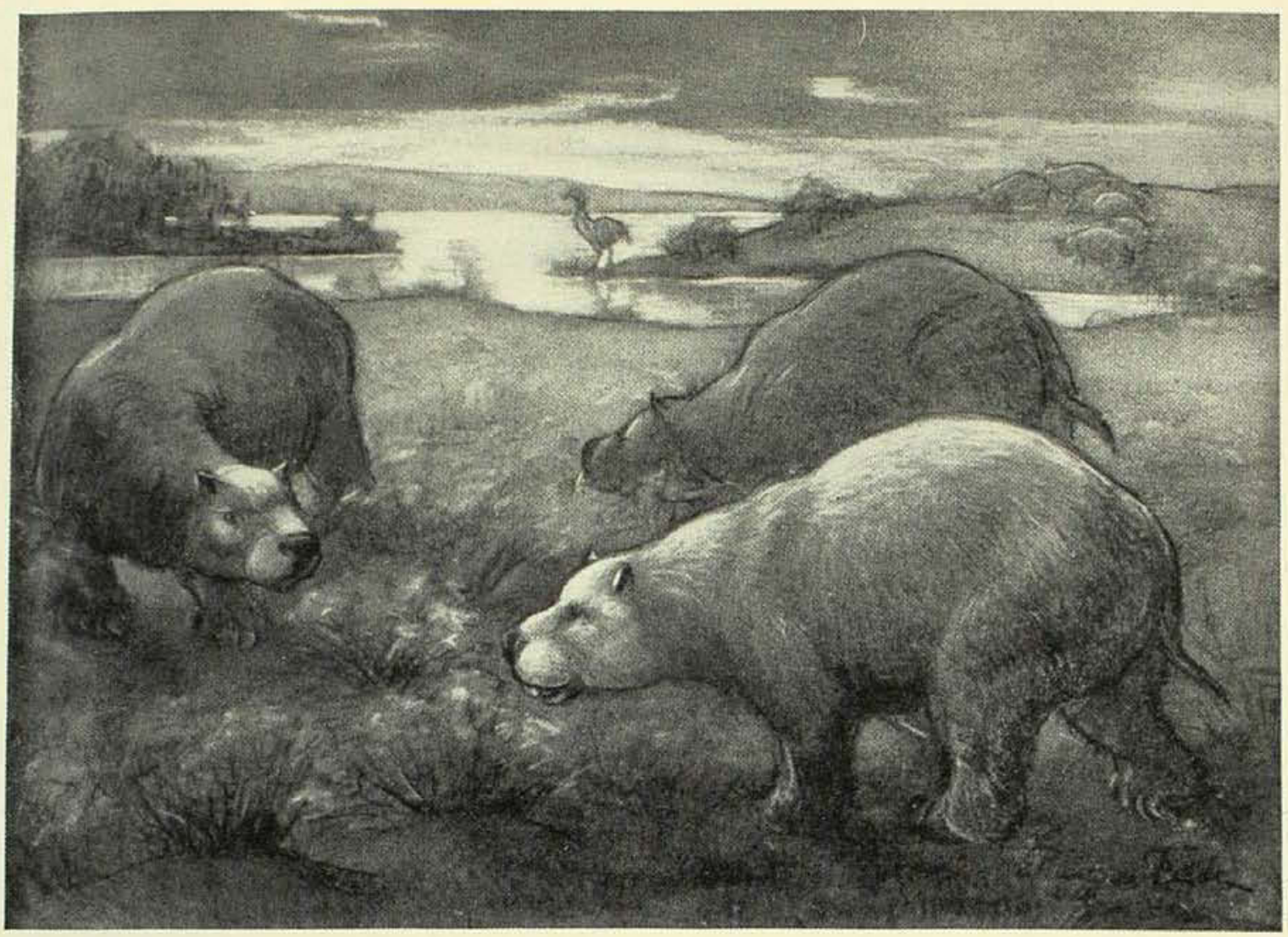

Restoration of Diprotodon by E. Rungius Fulda. It resembled a wombat but was considerably bigger.

[Courtesy of the American Museum of Natural History.

$\mathrm{I}^{\mathrm{T}}$

is a well known fact that in many groups of animals the modern forms are considerably smaller than their extinct relatives. The largest living reptile is dwarfed by the gigantic dinosaurs, which in ages past strode the earth or wallowed in the streams. An extinct North American turtle was about eleven feet in length; modern sloths are but pygmies in comparision with the huge extinct Megatherium, which rivalled the elephant in bulk. But it must not be supposed that these extinct monsters were the ancestors of their smaller living relations. As a general rule the course of evolution has been in the direction of increasing size ; for example the horse is descended through a long line of smaller ancestors of which the earliest known was no bigger than a fox, and the elephants of to-day have been traced back to forms about as large as a tapir. The overgrown giants of the past represented the last expiring efforts of dying races. They were offshoots from the general line of progress, they became too large, too unwieldy, too extreme, and so they perished, leaving no descendants. For success in life's race does not depend on brute strength or massive bulk.

\section{Australian Giants.}

As in other countries so in Australia the largest members of its fauna are extinct. During the Pleistocene period, which immediately preceded the era in which we are now living, there were giants in our land, and these have left their bones scattered 
along the flood plains of our rivers or deposited in limestone caves. It is the task of the palaeontologist to examine these bones, compare them with those of still living animals, piece them together, and describe for us the animals to which they belonged. The palaeontologist is something like the detective; he has a number of clues, sometimes few and elusive, sometimes abundant and satisfying, and these he follows up with the eagerness of any sleuth hound until he has constructed his case.

There is still much to learn concerning the former animal inhabitants of our continent, but already the tale of achievement is an inspiring one. We know, for example, that Palorchestes, which resembled the living kangaroos, had a skull about as large as that of a horse ; a restored model of this prehistoric monster may be seen in the Australian Museum. Nototherium was about the size of a hippopotamus, and Diprotodon was as large as, or even larger than a full grown rhinoceros. The "pouched lion," Thylacoleo, described by Owen as " one of the fellest and most destructive of predatory beasts," was not much smaller than the lion of to-day. All these belonged to the marsupial order, which still forms the most characteristic feature of the mammalian life of Australia. Indeed there is little doubt but that Australia was cut off from the rest of the world at a time when all the continents, including Australia, were inhabited by marsupials, and before the higher (placental) mammals had evolved. The few bats and rodents that straggled into Australia at a later date, and the dingo, which was introduced by man, were not original members of our fauna.

\section{Discovery OF the Diprotodon.}

This is the largest known marsupial, living or fossil. The history of its discovery, and of the steps by which its affinities were traced, is very interesting. Apparently its bones were first found in the Wellington Caves, New South Wales, about the year 1830. Mr. George Rankin of Bathurst appears to have been the discoverer of the fossiliferous cave earth, and he brought its occurrence under the notice of Major Thomas L. Mitchell, Surveyor-General, a

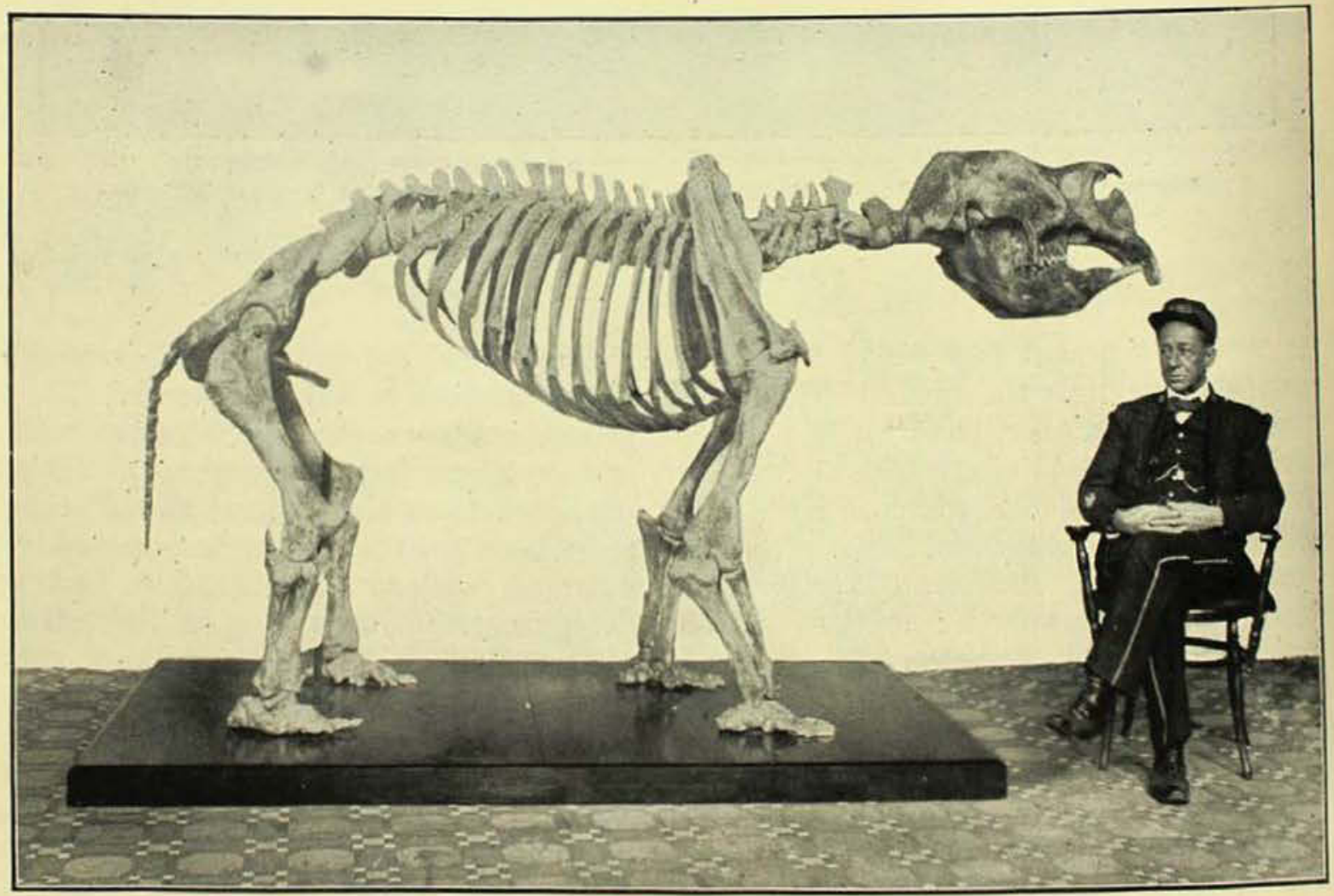

Cast of Diprotodon skeleton mounted in the Australian Museum from replicas of the original bones in the South Australian Museum.

[Photo.-G. C. Clutton. 
worthy pioneer of Australian science. In a paper dated at Sydney 14th October, 1830, and published in the Proceedings of the Geological Society of London, April, 1831, Mitchell described the limestone caves of the Wellington Valley and referred to the discovery of bones belonging to various types of still living marsupials, and of two bones, " not agreeing with those of any of the animals at present known to exist in New South Wales." One of these was part of the thigh bone of the Diprotodon, the other a fragment of its jaw. But so little did these remains resemble the bones of existing marsupials, that, when they were submitted to the foremost comparative anatomists of Europe, including Owen and Cuvier, these learned men were unable to place them correctly, and variously supposed them to be the bones of a dugong, a hippopotamus, an elephant, a mastodon and a deinotherium, these last two being extinct forms related to the elephant. This disposes of the popular and picturesque belief that a skilled palaeontologist can reconstruct an entire animal from a single bone; he can make a good guess, but only if the bone has very definite and characteristic features, and resembles more or less closely that of a well known form, living or fossil. Thus Owen, with no other evidence than that afforded by a broken thigh bone, was able to deduce the former existence in New Zealand of large flightless birds, the Moas, allied to the ostriches.

Evidently the Diprotodon in its time roamed widely over the Australian continent, for its remains have been discovered in every State, buried in sand and gravel along the banks of the rivers, or embedded in the earth which has accumulated on the floors of limestone caverns. Caves are often repositories for the bones of animals, which either made their homes there, were carried in by flesh-eating enemies, or, possibly more often, fell down sinks and chimneys, or were washed in by floods. Probably the Diprotodon was not a cave dweller, nor the victim of carnivores, but became entombed in the Wellington and other caves by misadventure.

By the exertions of Sir Thomas Mitchell, Dr. George Bennett, and other enthusiastic workers in the cause of Australian science, a goodly collection of Diprotodon bones was soon secured, including a nearly complete

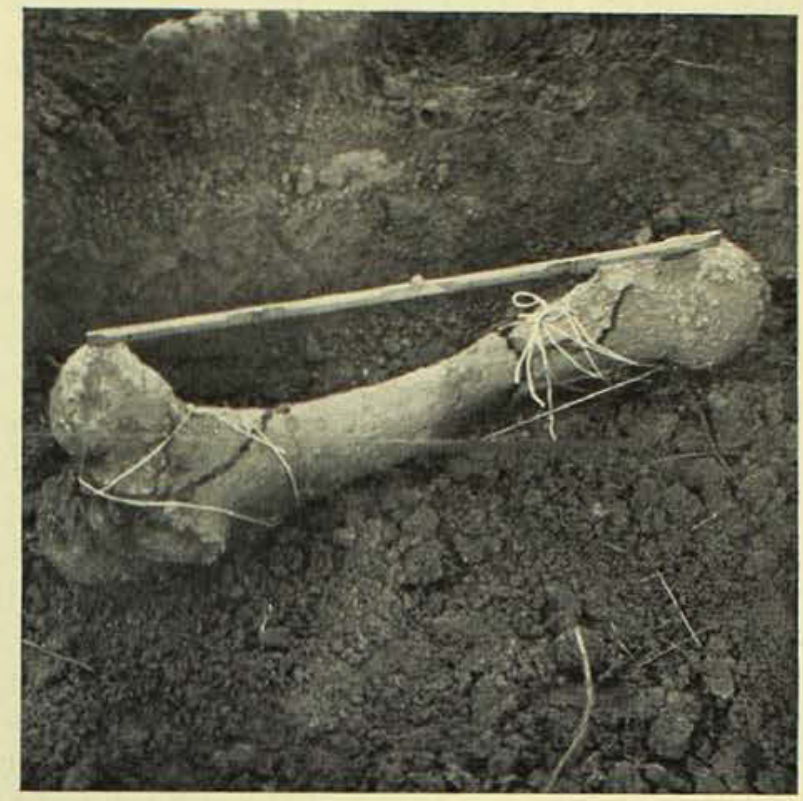

Thigh bone of Diprotodon found in the bed of a creek near Mullaley, New South Wales. The bone is nearly two feet long and is very massive. [Photo. -K. M. Cobb.

skull, of about three feet in length, from the Darling Downs, Queensland. With better material in front of him, Owen soon recognised that he was dealing with a gigantic member of the marsupial order which he called Diprotodon meaning "two front teeth." This name was first published in Mitchell's Three Expeditions into the Interior of Eastern Australia, 1838, but years elapsed before Owen was in a position to give an adequate description of this strange beast. In his classic work Researches on the Fossil Remains of the Extinct Marsupials of Australia, published in 1877 , he writes: "Of no extinct animal of which a passing glimpse, as it were, had thus been caught, did I ever feel more eager to acquire fuller knowledge than of this huge Marsupial. No chase can equal the excitement of that in which, bit by bit, and year after year, one captures the elements of reconstructing the entire creature of which a single tooth or fragment of bone may have initiated the quest."

It is gratifying to note that the Australian Museum played an important part in this fascinating quest. Dr. George Bennett was one of our Trustees, and the rich bone beds of the Wellington Caves were exploited under the guidance of Gerard Krefft, a former Curator.

Owen did not live to see a complete skeleton of the Diprotodon. He knew little 
or nothing of its foot structure, and in the restored drawing which was prepared under his direction, he was constrained to represent it standing amid tall grass, so that this deficiency might not obtrude. Fortunately this lack has been supplied by more recent discoveries, described below.

\section{Its APPEARANCE.}

What manner of animal was the Diprotodon, and what was its appearance when alive? It may seem an impossible task to deduce the bodily shape and proportions of an animal from the structure and dimensions of the disarticulated bones. But the bony skeleton is the scaffolding or support for the muscles, and from the size and arrangement of its bones, and by close study of their crests and ridges, which served for the attachment of muscles, and of the facets by which the bones were articulated, a skilled anatomist can learn much. Thus we know that the Diprotodon was somewhat like a wombat, that it walked on all fours and did not hop on its hind legs like the kangaroo, for its massive fore and hind legs were about equal in length. It stood about six feet high, and was about ten feet in length. It had a huge head and a thick strong neck. In the front of its upper jaw was a pair of enormous incisor teeth, chisel-like, with enamel on the front only, so that their sharp cutting edge was always maintained in good condition. These teeth were open at the roots and continually growing like those of the rabbit and other gnawing animals. Behind these were two pairs of smaller incisors, each pair meeting in the middle line of the palate. In the lower jaw was only one pair of incisors, which were very large, directed almost straight forward, and nearly cylindrical in section. Behind the incisors was a long gap succeeded by the grinding teeth, each of which carried a pair of prominent transverse ridges. Evidently the teeth were well adapted for cropping and masticating tough vegetation. Its feet were very peculiar in structure. It was a plantigrade animal, that is it walked on the palms of its hands and the soles of its feet. Its fingers and toes were almost diminutive in comparison with the rest of its body, and its toes were twisted inwards. But the most interesting feature about its foot structure is the clear evidence that this bulky animal was a descendant of tree-climbing ancestors, for its big toe was placed almost at right angles to the others, or was, as it is called, opposable, so that it could be used for grasping. This furnishes a good example of that much abused saying, "It is the exception which proves the rule," for, though all marsupials bear the marks of their descent from arboreal progenitors, it is very striking that, in the exceptional case of this massive brute, its ancient heritage can still be traced in its bones.

\section{A Diprotodon Cemetery.}

A wonderful series of Diprotodon remains were found some years ago at Lake Callabonna in Central Australia, about 600 miles north of Adelaide. Embedded in the mud of a salt lagoon, about three feet below the surface hundreds of more or less complete skeletons were discovered and dug out by a party under the leadership of the late distinguished Director of the South Australian Museum, Professor E. C. Stirling. It is surmised that the animals had got bogged in the soft mud, probably in seeking water in a dry season, and the inference has been made that the "Dead Heart of Australia" was formerly well supplied with water, perhaps studded with fresh water lakes round the shores of which roamed great herds of Diprotodon. With increasing aridity water and food supplies dwindled, and only dry bones remain to tell the tale of former plenty.

From the abundant remains found at Lake Callabonna Professor Stirling and his skilled assistants were able to reconstruct a complete skeleton, including the feet. Plaster replicas of this skeleton have now been supplied to the leading museums of the world; one of these can be seen in the osteo. logical gallery of the Australian Museum, with the skeleton of a wombat and a kangaroo placed alongside for comparison.

\section{The Food of Diprotodon.}

Associated with the skeletons discovered at Lake Callabonna were found the remains of leaves, stalks, and twigs, the ends of which were often frayed or crushed, as if by the action of teeth. These vegetables remains were submitted to Professor Radlkofer of Munich, who pronounced them to belong to various scrubs allied to the salt-bush, which even to-day furnishes much of the food supply for the stock which pastures in the district round the lake. 


\title{
As Extinct as the Dodo.
}

\author{
By Tom Iredale.
}

$\mathrm{T}^{\mathrm{H}}$

HIS saying is now a current expression indicating that something of the past is being referred to. What the Dodo was, and why it became extinct are questions not so quickly answered, and, as we can learn from its experience, we may outline its fate. Sometime in the past a number of pigeons found themselves isolated upon a fertile island in the Southern Indian Ocean ; food was plentiful even on the ground, and could be eaten at leisure without fear of enemies, as there were none. Such an elysium suited these thoughtless birds, and

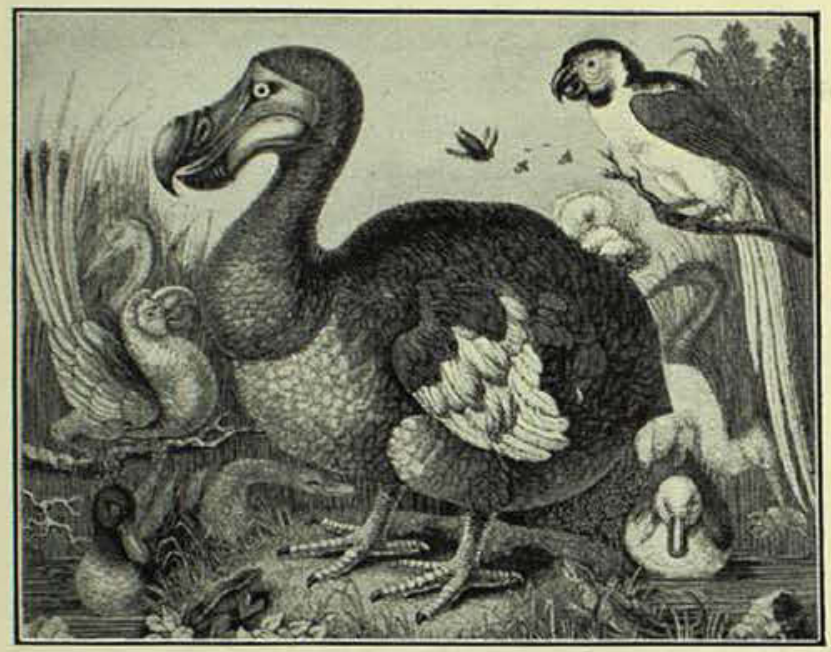

The Dodo, as it looked when alive, from the painting in the British Museum.

they ate and slept without thought of the future. Hitherto their life had been a round of food snatching and flying, roosting on the highest trees; in this little paradise there was no need to hurry and none to fly. Thus the birds existed ; getting bigger and bigger, their bills also enlarging to cope with their appetites, their legs becoming very thick and strong to support their bulk, and their wings decreasing through disuse into mere caricatures.

So they degenerated into huge perambulating balls - fat, heavy, ungainly, slow of foot and incapable of flight. Years passed, and then into this Garden of Eden came, not a serpent, but a human being. Columbus discovered America, and the age of discovery began; and almost immediately vessels sailed southward and, meeting gales, turned back from the Cape of Storms, but a hardier voyager with better luck, rounded and rechristened the cape Good Hope. But it was bad luck for the Dodo. Just round this cape lay Mauritius, its island home, and, as by the time the little sailing vessel rounded the Cape the stock of provisions was very low, these helpless birds formed a welcome feast for the half-starved sailors. Few accounts have been left of the slaughter, but the following extracts are suggestive: "It gapes huge wide as being naturally very voracious. Its body is fat. . . . It is a slow paced and stupid bird, and which easily becomes a prey to the fowlers. The flesh, especially on the breast, is fat, esculent and so copious, that three or four Dodos will sometimes suffice to fill an hundred seamen's bellies. If they be old, or not too well boiled, they are of difficult concoction, and are salted and stored up for provisions of victual." Another writer, more fastidious, records : "Her body is round and extreme fat, her slow pace begets that corpulencie: few of them weigh less than fifty pounds: better to the eye than to the stomach: greasie appetites may perhaps commend them." The latest writer simply notes : "Dodos whose flesh is very hard."

Harried by the sailors, and probably worried by pigs introduced by them, this peace-loving inoffensive bird, soon disappeared entirely from the land of the living.

\section{The Great Auk.}

A parallel case is that of the Great Auk of the Northern Atlantic, which was simply a huge, lazy, flightless Razor Bill. There is no similar bird in the Southern Hemisphere, but Razor Bills, Guillemots, and Little Auks form huge colonies along the rocky shores of the north, and these fly to and from their eggs laid on inaccessible cliffs. This great Razor Bill was adept in the water, swimming and eating, but bred on isolated rocks in the sea. As it degenerated, through lack of practice in flight, its egg was laid nearer and nearer the sea, so that it could more easily 
scramble to it. When its haunts were discovered by man its fate was sealed. Whilst on the water it was safe, but wherever it landed man could follow, and it soon shared the fate of the Dodo. Nature is supposed to have assisted in this case through a volcanic outburst destroying its chief nesting place. Occasionally Great Auk's eggs appear for sale, and, the exact number now existing being known, there is keen competition to become the possessor of such a rarity : at such times the sad story of the bird itself becomes a newspaper topic for a day or two.

These two examples are characteristic of a score of species whose extermination is

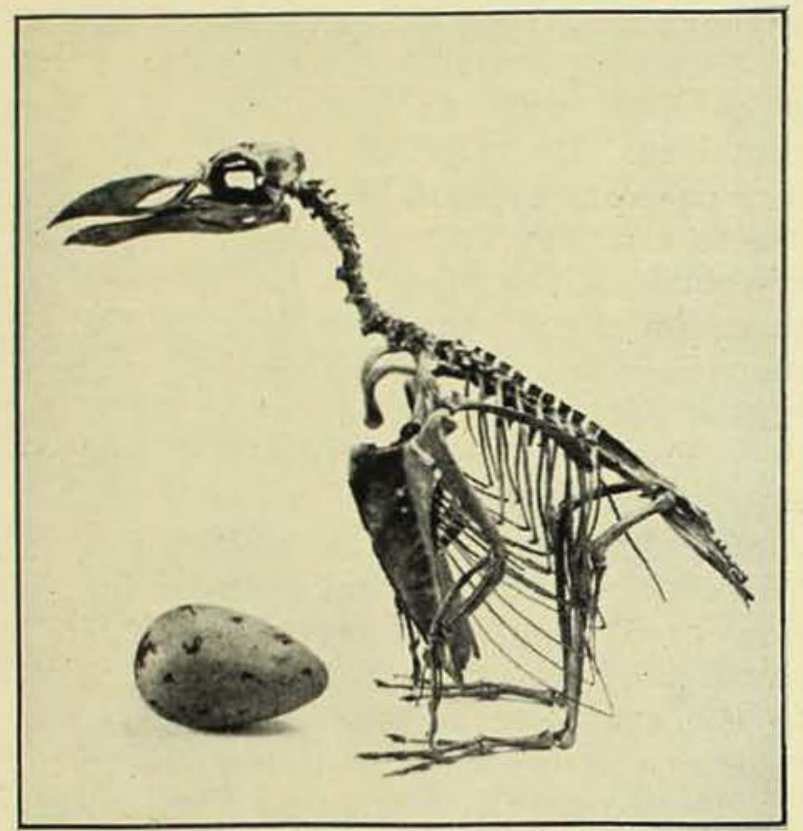

The Great Auk (Alca impennis). The Great Auk has been extinct for close on a century, the last living example having been captured in Waterford Harbour, Ireland, during 1834. It is the analogue in the Arctic Regions of the Penguins in the Antarctic, and was, as they are, unable to fly. From the exhibit in the Australian Museum [Photo.-G. C. Clutton.

directly due to the intrusion of man into a haven of peace, whose dwellers had become unfitted to struggle against a new enemy.

\section{The Aepyornis and MoA.}

Other cases of extinction are not so simply explained, such as those of the Aepyornis of Madagasear and the Moas of New Zealand.

These were degenerates of large size and flightless, but they possessed very long and stout legs, even as the Ostrich, Emu, Rhea, and Cassowary, which still live. It may be that lack of practice on the part of the former failed to develop speed such as is known of the survivors, the speed of the Emu having recently been stated to exceed forty miles an hour, measured on the speedometer of a motor car. What happened to the Aepyornis can scarcely be guessed, but traditions suggest that Moas were exterminated by the Maoris and their predecessors. However Nature apparently assisted, as Moas were very numerous, abundant remains being found everywhere in New Zealand, and sometimes under such conditions as would indicate that some natural catastrophe killed the birds. As far as we know the Moa had no natural enemies except perhaps a huge eagle which itself vanished as its food supply failed.

\section{The Passenger Pigeon.}

The enigma of bird extermination is the Passenger Pigeon of America. Its oft-told story may be condensed into a few sentences : "The air was literally filled with pigeons. The light of the noonday was obscured as by an eclipse. The pigeons were still passing in undiminished numbers and continued to do so for three days in succession . . . Let us take a column of one mile in breadth, which is far below the average size, and suppose it passing over us at a rate of a mile per minute." From this a calculation was made of "One billion, one hundred and fifteen millions, one hundred and thirty-six thousand pigeons in one flock." This was written in 1813, and in 1913 the Passenger Pigeon had ceased to exist. As this bird was one of the fastest flying birds known, capable of great exertion and full of tireless energy, it is difficult to account for its fate. The only suggestion that seems worth consideration is that the advent of the European into America brought some disease which became epidemic, and thus exterminated this beautiful bird. No other explanation seems feasible, and the epidemic hypothesis has parallels among human beings. When Europeans first sailed the southern seas they brought with them some diseases of little consequence to themselves, but which proved fatally epidemic to the natives of some island groups.

\section{The Swamp Hen.}

In the dim past a bird not unlike a hen flew southward to New Zealand, Australia and the intervening islands. The birds that 


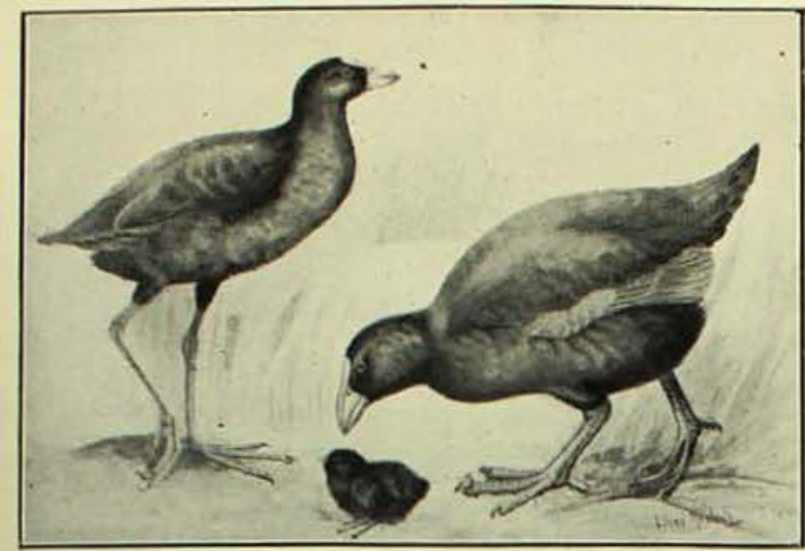

The Swamp Hen of New Zealand, and the Notornis, its nearly extinct relative.

came to Australia met with competition from other birds, and so preserved their power of flight and slimness through exercise thereof. The birds that reached New Zealand found an avian paradise and drifted, once again degenerating into fat, clumsy, flightless birds, so that when enemies arrived they were driven into the wilds and few survived. At the same time similar birds which had preserved their power of flight arrived, and, being more active, became serious competitors of the earlier arrivals. Thus when Europeans interested in bird life came to New Zealand they saw only the newcomer, and were for many years unaware of the continued existence of the older form in the wild west. When one was found it was regar ded as the last of its race, but fortunately there are still a few survivors to furnish the complete history. The newcomer is known as the Swamp Hen and the older bird as Notornis, and a near relative of the former is the White Gallinule of Lord Howe Island. On this little island a few swamp Hens found a safe spot uninhabited except by other similarly inclined fowls. The Swamp Hen did not grow very large and fat as it had to scratch for its living owing to the scanty food supplies on this small island, but it did lose its flying powers, and, when Phillip's ships arrived at Sydney, its doom was sealed. Voyaging to Norfolk Island one of these ships discovered Lord Howe Island, and found there turtles and birds like coots good to eat. In a few years there were no coots, they had all been eaten, and many other birds, pigeons, parrots, parrakeets and petrels, shared their fate. How one of the last named escaped extermination is a little romance of its own. It came to land only to breed, 1 he rest of the year living at sea, flying vigorously and keeping very fit in every sense. When it arrived at Norfolk Island to breed in holes on the sides of Mount Pitt in the last years of the eighteenth century, it found a lot of hungry men waiting to eat it. This was entirely a new experience, and thousands upon thousands were slaughtered. However it could fly, and that saved it from extinction. Finding Norfolk Island too unhealthy the survivors deserted that locality, and began to breed on the inaccessible tops of Mounts Lidgbird and Gower, Lord Howe Island, where they persist at the present time. Thus through relying upon its defensive means of flight, its safety has been assured, while all its contemporaries on the same island, incapable of escape, have been exterminated.

\section{The Semi-Woodcock.}

A term recently coined for existing animals that have persisted through untold ages while most of their contemporaries have perished, is "living fossil." As an instance may be cited the Semi-Woodcock of the islands south of New Zealand. It is suggested that this little bird has been exterminated on the large islands of New Zealand, and has persisted on the uninhabited and practically uninhabitable islets, retaining its ancient form. In structure, both externally and internally, it looks its name; it is a semi-woodcock and living fossil. The woodcock (unfortunately we do not possess one in Australia though the mountains of New Guinea harbour one) is a game bird

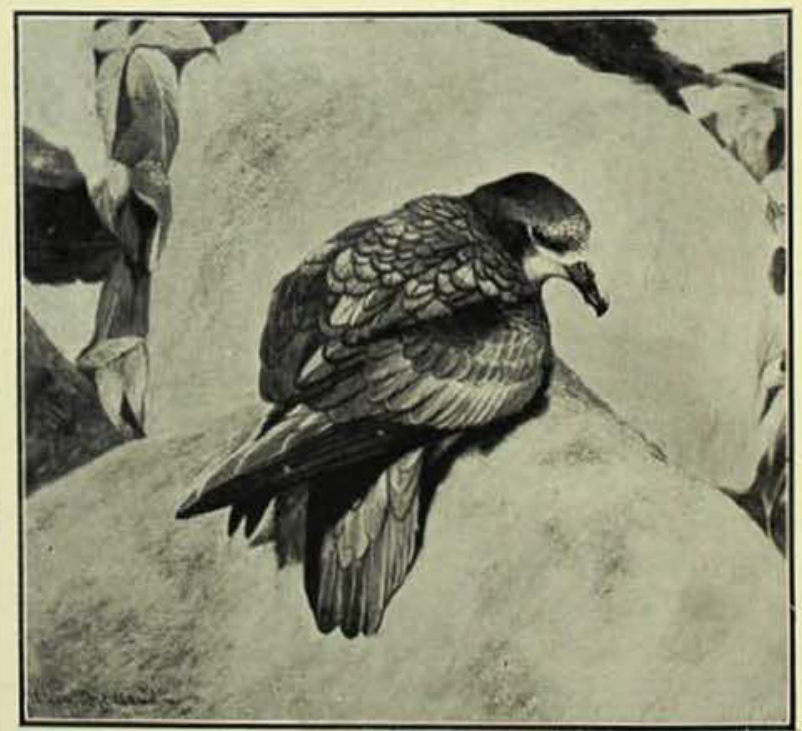

The Norfolk Island Petrel, extinct on that island though still living on Lord Howe Island. 
"good to eat," but it is a good flier and keeps moving, and thus remains a living form.

From relatives of woodcocks the swifter flying snipes have developed and these visit Australia every winter, also being "good to eat." These birds are shy, wary, good fliers, capable of taking care of themselves in every way, and exercise of wit and skill is necessary before their edible qualities can be tested. The little New Zealand Semi-Woodcock is flightless, but it has never grown bulky, for only a scanty living can be procured upon the inhospitable rocky islets, its only and last dwelling place. It can be justly termed a living fossil and it is only a matter of a few years before its name will be enrolled on the list of the past.

\section{Disappearing Australian Birds.}

Now, what of Australia proper? How does our homeland fare in the matter of extinct birds, and what steps are being taken to prevent threatening extermination? The matter is one that should engage the attention of every thinking Australian, as the bird life of Australia is a precious and unique asset. The word unique is used here in its correct sense, as the Australian bird fauna is a wonderful series of oldtime novelties, living fossils, birds of paradise, bower birds, mound builders, and others equally peculiar. All of these have developed through lack of enemies and competition, Australia being a paradise for birds until the advent of man. Not satisfied with his own means of destruction folly has led man to introduce rabbits, foxes, sparrows, starlings and now, after all the bitter lessons of the past, even stoats and weasels are suggested. A few years of the latter would enrich the roll of extinct Australian birds at an alarming rate. As indicated above, man has been responsible for the extermination of many interesting bird forms, but most of these were killed for food, not wantonly destroyed. The Passenger Pigeon shows that healthy fast-flying birds will succumb to causes unappreciated by us at present, while in New Zealand the scarcity of native birds is regarded as entirely due to the introduction of foreign birds and mammals. It is a matter of only a very few years before practically the whole of the New Zealand avifauna will be written up under the title of Extinct Birds.

As a warning it should be mentioned that

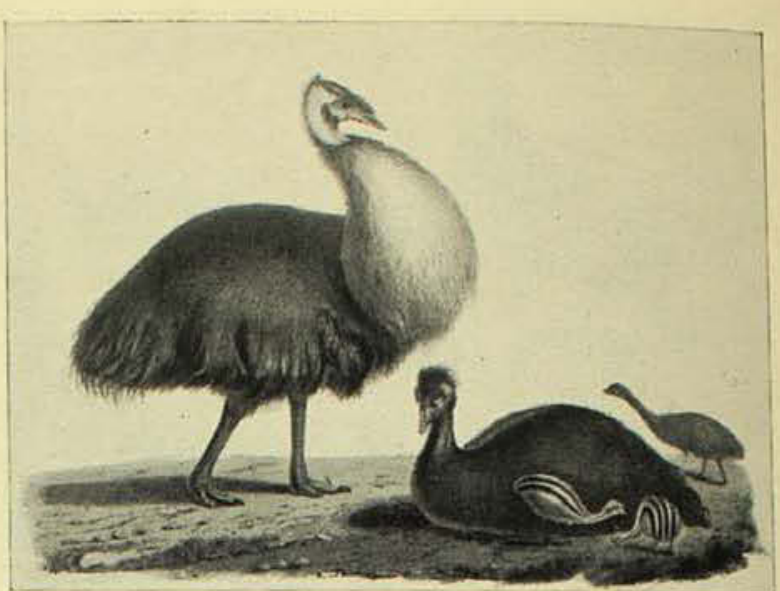

Kangaroo Island Emu, painted from life by Lesueur, the naturalist who accompanied Peron on his voyage of discovery to Australia in the years 1800-1804.

there are a number of Australian birds on the border line. Very little more disturbance will prove their downfall, and the apathy of the very people who should treasure them is amazing.

With one of Phillip's ships came an artist, who was employed by White, the Surgeon General of the settlement, to paint subjects of natural history. Some hundreds of paintings were made and these are preserved in the British Museum (a better location would have been the Mitchell Library, Sydney), and these paintings show many birds which do not live near Sydney at the present time, and some of which do not appear to exist in Australia at all. It may be that these have been exterminated, but we cannot tell. It is sufficient to point the moral that unless care is taken to preserve what now exists, in another hundred years queries may be raised concerning the present living forms.

Fortunately for Australian bird life we have not a long record of fatalities to chronicle, but one interesting bird has passed out of existence within the last hundred years. Kangaroo Island was so named on account of the number of kangaroos met with there, and associated with them were emus, which were apparently quite common. The first visitor took some birds back to France, and maybe some also went to England, but there is not now any living Kangaroo Island Emu, and only a couple of skins and skeletons to prove their former existence. A good painting was made by the artist attached to the French Expedition, and this is reproduced. 


\title{
The Story of a Rock Dredged from the Sea.
}

\author{
By T. Hodge Smith.
}

THR ROUGH the kindness of Mr. C. W. Mulvey, manager of the New State Fish and Ice Company, the Trustees have been presented with a slab of recently formed rock dredged up from the sea floor 400 feet below the surface at a point due east of Montague Island, New South Wales. The illustration shows how crowded this rock is with scallops (Pecten meridionalis Tate) and other bivalve shells. It is a curious thing that none of the shells found in this rock live at that depth at all, but are found on the sea shore and in shallow water. More perplexing still, some of them are not found on the coast of New South Wales but are found on the shores of Tasmania. If you look more closely at the illustration you will find that the sand grains which constitute the rock are very coarse. Now this is instructive, for such coarse sediments are found as a rule only quite close to the shore line. In the deeper waters the dredge would bring up less coarse material, and at a depth of four hundred feet only quite fine sand and mud would be found.

Then how came this slab of coarse sandstone, crowded with littoral shells to be found at such a depth? It is just the sort of thing we would expect to find forming near the sea shore, and indeed it must have been formed quite close to one. How could we ever have a sea shore where now we have four hundred feet of water? Those of you who have lived in active volcanic regions will probably have no difficulty in imagining how a sea shore could subsequently be covered with so great a depth of water. On the other hand, those who have not travelled to such places may be inclined to look on the coast of New South Wales as a permanent feature which nothing could shift. We are now singularly free from any volcanic activity, but this has not always been the case. The aboriginals, in their traditions handed down from generation to generation, tell us of volcanoes in Victoria ; and indeed we find extinct voleanic cones which have every aspect of being very recent.
Volcanoes are generally associated with earth movements and therefore we may safely conclude that in recent times we have had earth movements in Australia.

During the Tertiary period, probably before man appeared on the face of the earth, New South Wales was a vast plain not elevated very much above sea level. Then as if nature had tired of the monotony of so vast a plain, marshalling her untold forces she folded the earth's crust so as to form the present-day Main Divide. This was not a sudden movement, but an exceedingly slow one, and was accompanied or perhaps followed by a corresponding subsidence of the coast. Evidence of this subsidence is seen in the drowned valleys of Port Jackson, Broken Bay, and other inlets.

This brings us back to the story of our rock. The shells now found in the rock once lived on an old beach. When they died they became buried in the sand of this beach just as shells do to-day. There is however one remarkable feature about this old beach, that is the enormous number of shells crowded into so small a space. One would probably have to travel far and search patiently to find a beach so rich in shells of such a size.

We may next enquire how the sand of the beach so crowded with shells became consolidated into rock. There are a number of ways in which this could happen, but most probably this rock was formed by the action of fresh water. On some of our beaches to day, as at Narrabeen, we find that in places the sand has become consolidated into sandstone, and of course the shells that are contained in the sand become enclosed in the solid rock. Where this occurs we generally find that fresh water enters the beach. Natural water always contains such gases as oxygen and carbonic acid in solution. Water charged with carbon acid gas has the property of dissolving calcium carbonate of which the shells are mostly composed. Thus some of the shell material is brought into solution until the water becomes 


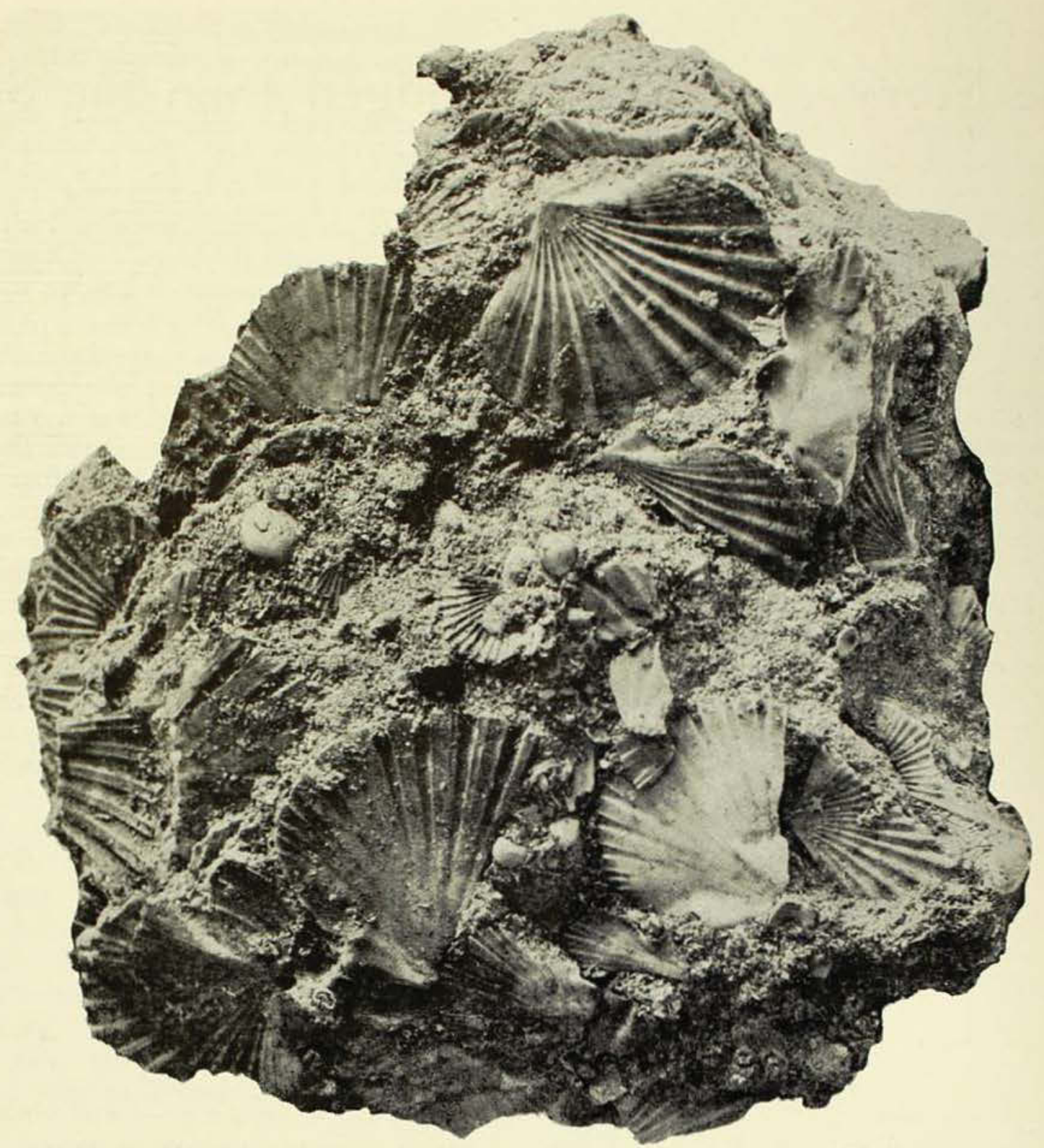

A slab of sand-stone crowded with scallops (Pecten meridionalis) and other bivalves. This was dredged from a depth of seventy fathoms east of Montague Island, New South Wales.

[Photo.-G. C. Clutton.

saturated, and then the reverse process takes place and calcium carbonate is deposited. It is this deposition of the calcium carbonate that cements the sand grains together to form solid rock.
Thus this rock which at first sight seemed so perplexing. fits in perfectly with the geological history of our coast and faithfully records the position and character of this old sea beach of New South Wales.
Recent donations include the following :A collection of objects illustrating the material culture of late German New Guinea by Mr. R. F. Armstrong; a number of ornaments from Papua by Mr. Albyn A. Stewart, a general collection of minerals, shells, etc., and ethnological objects by Mrs. E. D. Gray and Miss K. E. Harbutt; an interesting pot-shaped stone mortar from the Solomon Islands, by Mr. H. S. Hefferman. 


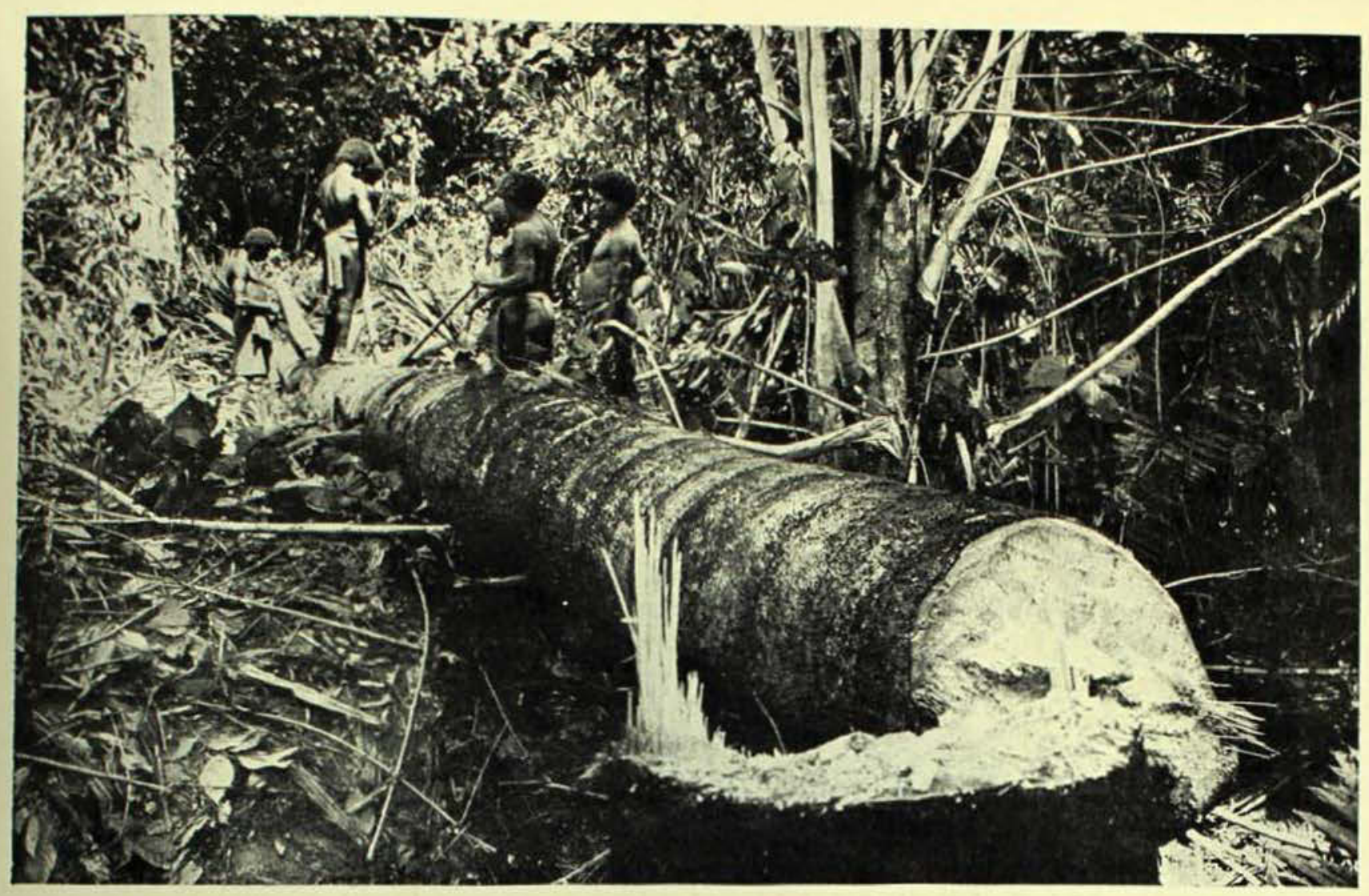

The Sago Palm felled. Observe the American axes employed.

[Photo.-Captain Frank Hurley.

\section{The Sago Industry of Papua.}

\section{By William W. Thorpe.}

The accompanying photographs are published by permission of Captain Frank Hurley, and may not be reproduced under any circumstances.

THE prevalent idea that, since vegetation grows so luxuriantly in the South Sea islands, the inhabitants can readily obtain sufficient food, is not always correct. Those who hold this view lose sight of the fact that in many cases the natives are still in the stone age so far as culture is concerned, and that their tools are extremely primitive. The Papuans and other New Guinea natives, many of whom have not been greatly influenced by contact with white civilization, have to toil hard in order to supply their needs. One of their greatest blessings is the sago palm, the use of which was introduced from the Malay Archipelago and which now furnishes a staple article of diet throughout New Guinea.

The Sago Palm (Metroxylon sagu) thrives abundantly on the fertile deltas and river flats, and the inhabitants of the districts where it does not grow so well obtain their supplies of the commodity by barter. Yearly expeditions from the east are made by fleets of lakatois (trade canoes), carrying cargoes of pottery, stone implements, and shell ornaments, which are bartered for sago with the Gulf natives, who are unable to manufacture these articles for themselves.

THE SAGO PALM.

The palm is a slow grower, generally taking twenty years to attain maturity, when it flowers, fruits, then seeds and dies. Sago, or sac-sac as it is called in New Guinea, is the pith of the tree, which, prepared in the native manner, forms a solid hard mass, quite unlike the granulated article with which we are so familiar.

When sago stocks are running low or a 
fleet of trading lakatois is expected to arrive, the sago getters sally forth to look for suitable palms. Fine tall trees with smooth trunks are preferred, and soon these are crashing down amongst the luxuriant under. growth. Felling was formerly done exclus. ively with stone hatchets, but now American axes are frequently used, and the natives are very skilful axemen. Where the "logging " site is some distance inland the trunks are rafted down the rivers and creeks.

When the tree is prone the next operation is to lop the crown with its immense fronds. This is performed with care, for the concave stalks will be needed later. To remove the rind or cortex, incisions are made along the trunk for its entire length, and the rind is then wedged or prised off. The heart of the palm, the sago itself, is now exposed. This is whitish in colour, has the consistency of cheese and is thickly permeated with tough fibrous strands. It is nearly pure starch and forms the reserve food supply which the palm has accumulated during its life to enable it to flower and seed before its death.
THE RAW MATERIAL.

The exposed pith has now to be broken down, and, while this is being done, large leaves are spread on the ground to keep it clean. Some of the men, or women, sit down facing the trunk, each with an implement known in the Gulf district as a mavara. This resembles an adze, but its working edge is really a tough and slightly cupped stick, set in an $\mathrm{L}$ shaped handle, the latter being a natural branch with portion of the trunk attached. While this party is busy chopping the pith others are constructing a flume with gigantic leaf stalks. These have a spreading base and are admirably adapted for making troughs. Twe or three of these concave stalks or spathes are overlapped and supported on crossed stakes, and a trough of the same kind is placed on the ground at the lower end of the flume. The chopped pith is placed in the upper end and well soused with water. The mass is kneaded vigorously so that the sago starch may be released from the fibres which bind it together. The water, now charged with sago, passes down the flume

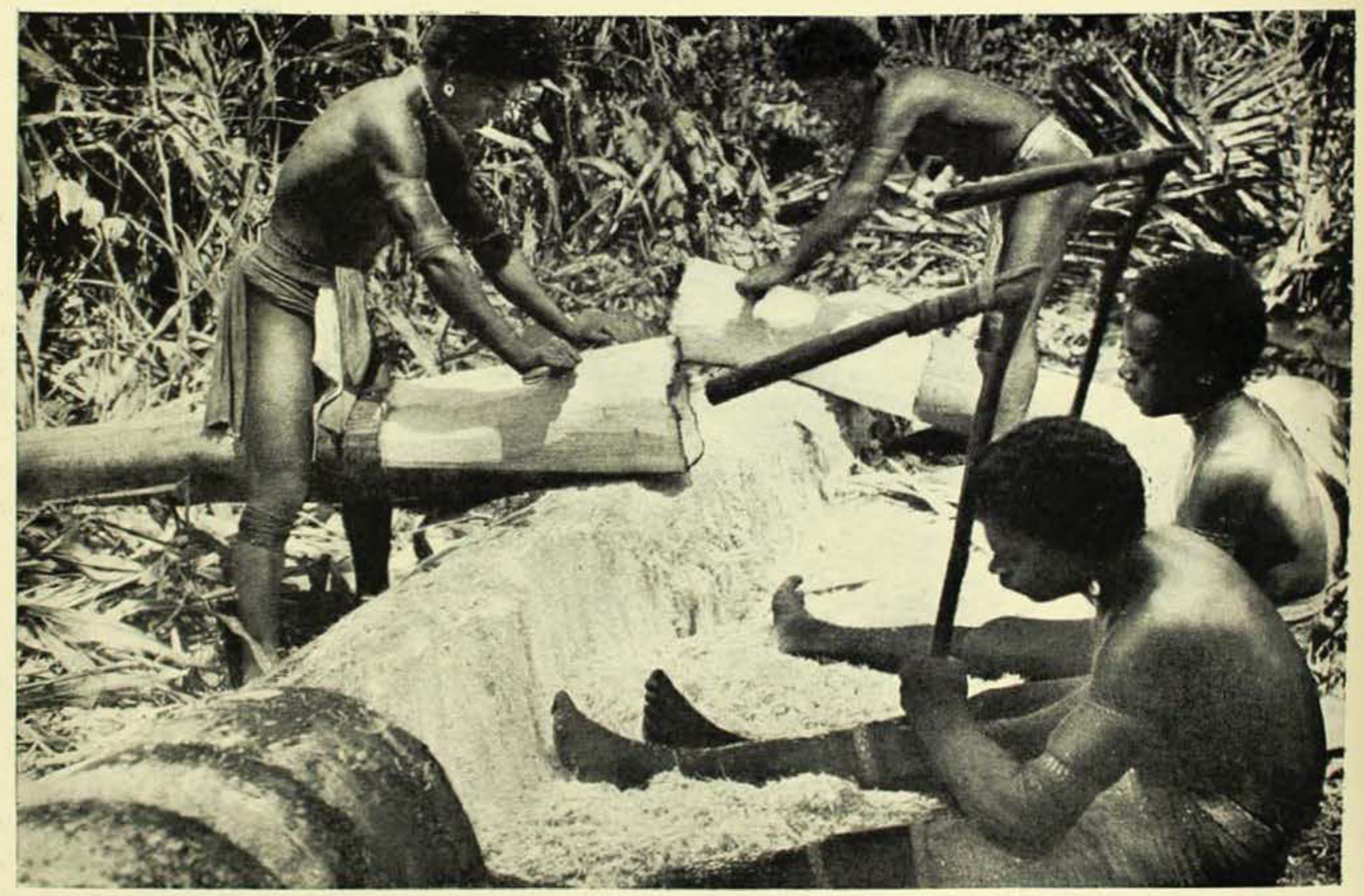

The rind, or cortex, having been removed, the next stage is the breaking down of the pith. Whilst this operation is in progress other natives are busily preparing spathes for a flume. 


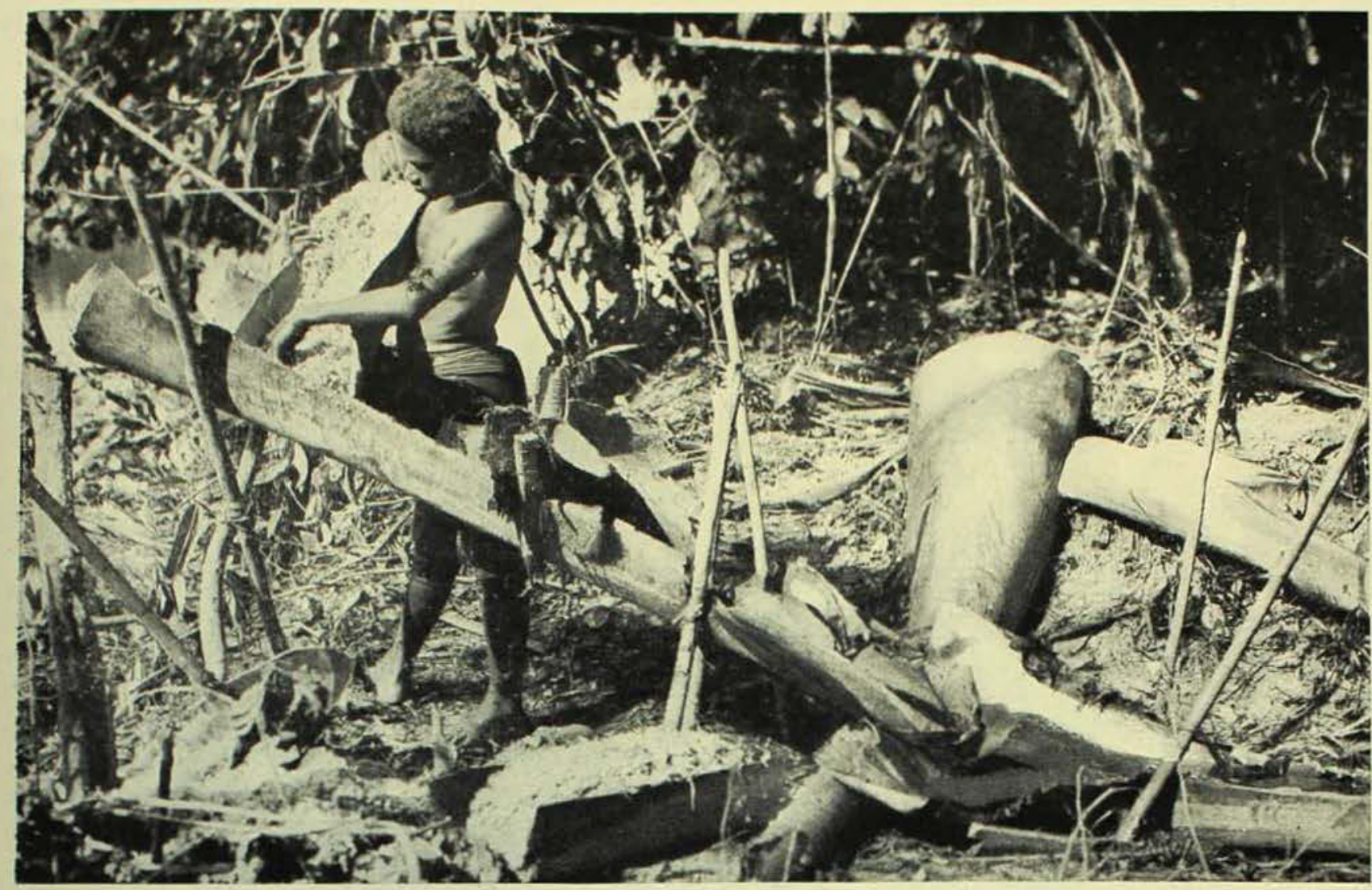

Placing the broken-down pith in the flume for washing. Note the strainer which collects the fibres, etc., during the process.

[Photo.-Captain Frank Hurley.

and in its descent is strained through a colander of coconut leaf sheath, or through a netted bag of fine mesh, and is received into the palm spathe trough, where the sago settles. When a sufficient quantity has been deposited, and has become partly solidified it is parcelled in palm leaf baskets. For trade purposes it is made into large bundles by wrapping the damp mass in interlaced palm leaves. A well grown tree will yield about two hundred pounds of wet sago, sufficient to sustain a family of five for about a month.

COOKING OPERATIONS.

Where pottery is obtainable the sago is boiled, usually with the addition of dried fish, crabs, or greens to improve its flavour, for by itself it is rather insipid. The more primitive method is to bake it into cakes in ground ovens. In Dutch New Guinea an earthenware utensil, which is practically a combination of the baking dish and patty tin so familiar to us, is used. It is about a foot long and about six inches wide and high, with a number of rectangular openings on the top into which the damp sago is put. Another method is to cook or roast the sago in bamboo tubes over an open fire.

\section{ARRIVAL OF LAKATOI FLEET.}

When the canoes arrive in the Gulf the visitors go ashore, where they are met by the headmen, who receive presents of shell ornaments. Each article has a definite value, and an equivalent is returned before the fleet sets sail again. Each trader selects a local native to act as his friend during the visit and to look after his interests. A dog or pig is now killed and given to the visitors, and all tabu restrictions are removed.

Early next morning pots of different sizes and shapes are brought ashore and ranged along the bank, each trader standing by his wares to await the prospective customers. The purchasers pass along and indicate their preferences by dropping two small lath- 
shaped pieces of wood into pots which take their fancy. Then both vendor and purchaser pass by again, and the tally sticks are removed, each party holding one as a check. When the business is completed the pots are removed to the huts of the buyers. Eventually the sago is produced and loaded into the lakatois. It is made up into packages of three different amounts, gorugoru, containing two hundred and fifty to three hundred and fifty pounds, turua, averaging eighty pounds, kokohara, forty pounds. The loaded canoes then return eastward, making one or two calls on the way. The coast natives keep a lookout for the homeward bound fleet, and its arrival, after an absence of about three months, is celebrated by feasting and merriment.

Sago has the great advantage over most vegetables that it will keepfor several months, forming a reserve food supply, a matter of great importance to these primitive people, especially those who live in districts which are unsuitable for cultivation.

The Papuan Government, which has always made the interests of the primitive people under its rule one of its first considerations, fully recognises the importance of the sago palm and has enacted strict ordinances for its protection.

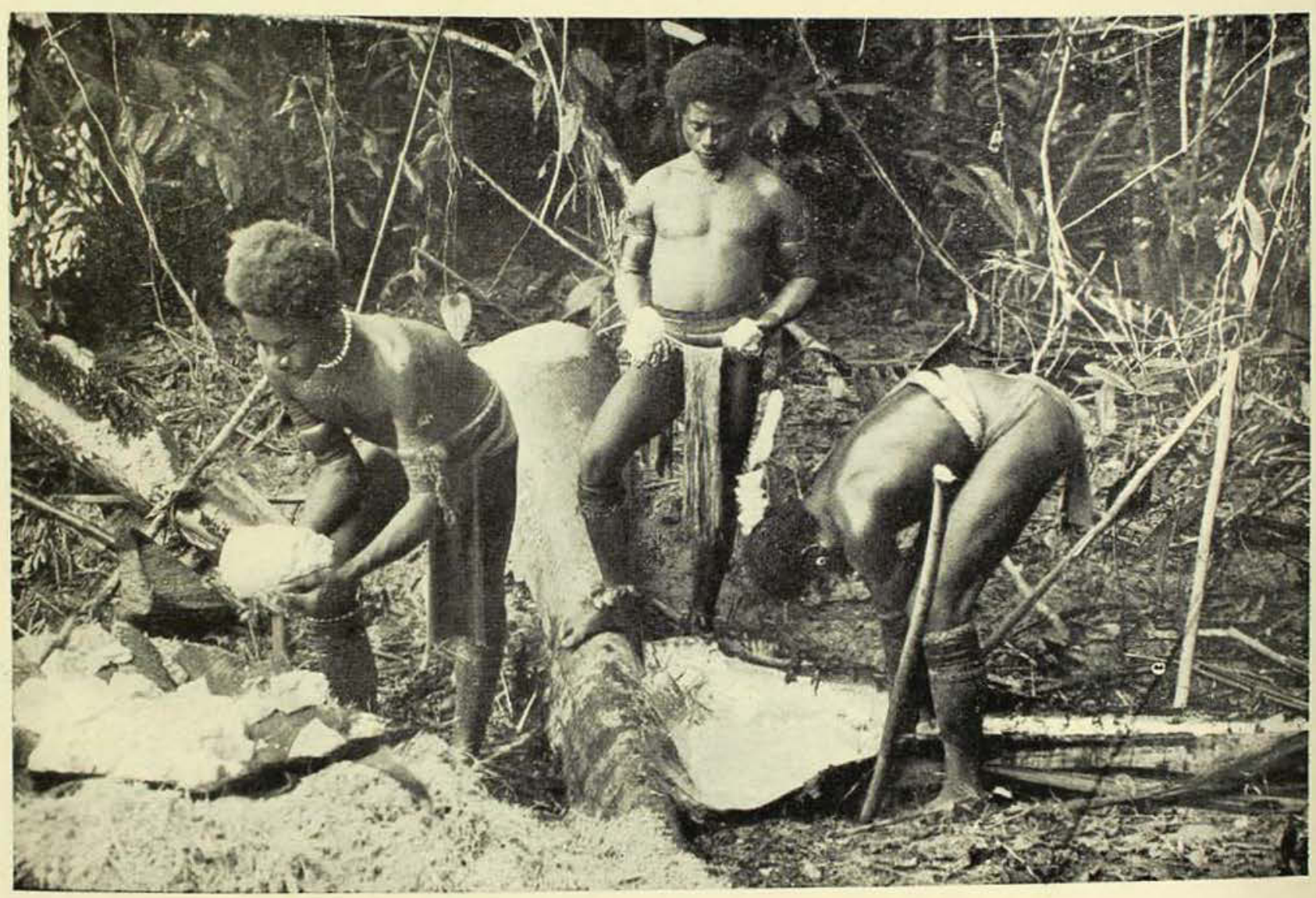

Removing and parcelling the sago. 


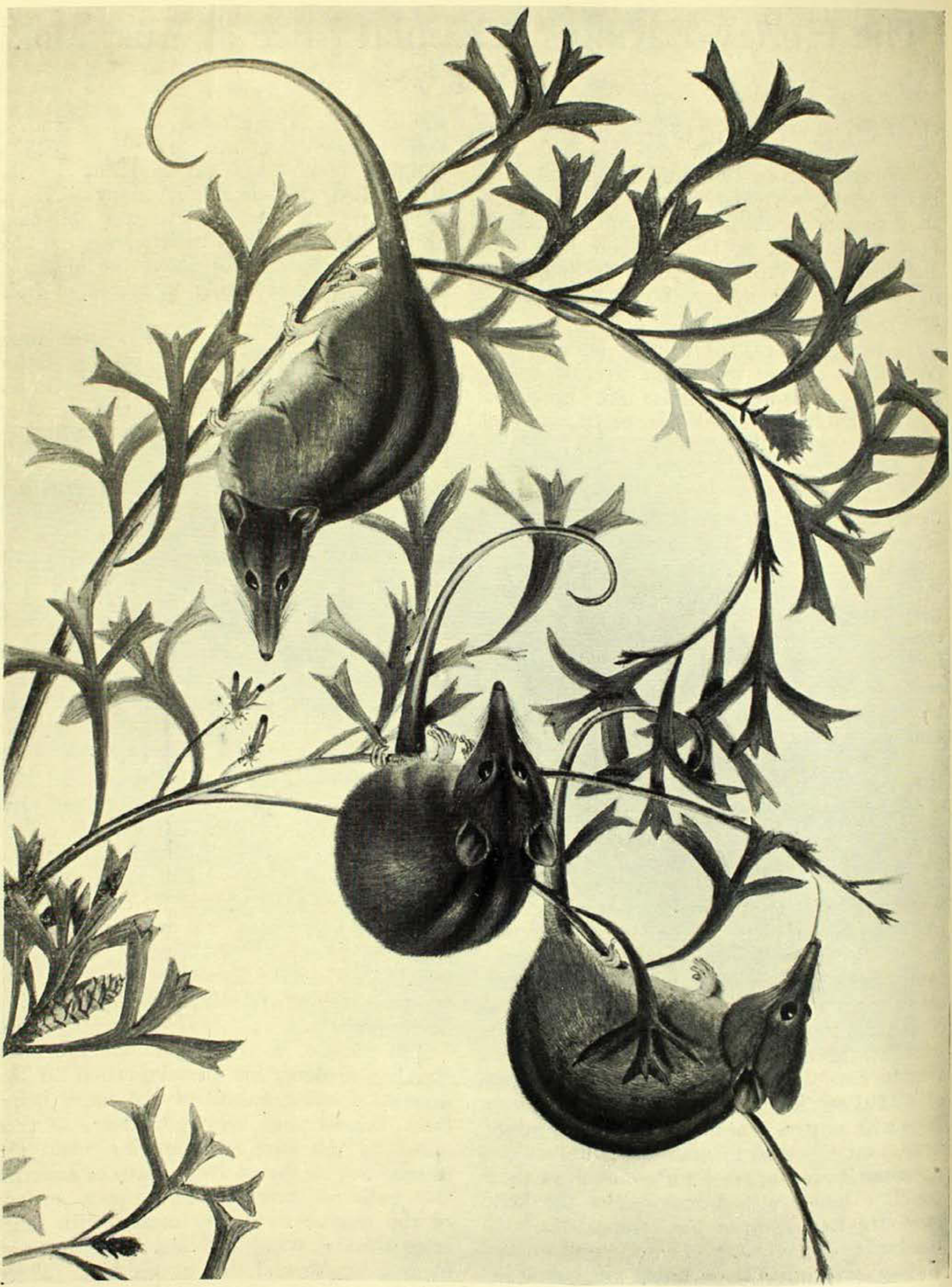

The Honey Mouse (Tarsipes spenserae) of Western Australia, which inhajits the south-western corner of that State, south of Perth where, until recently, specimens were caught. 


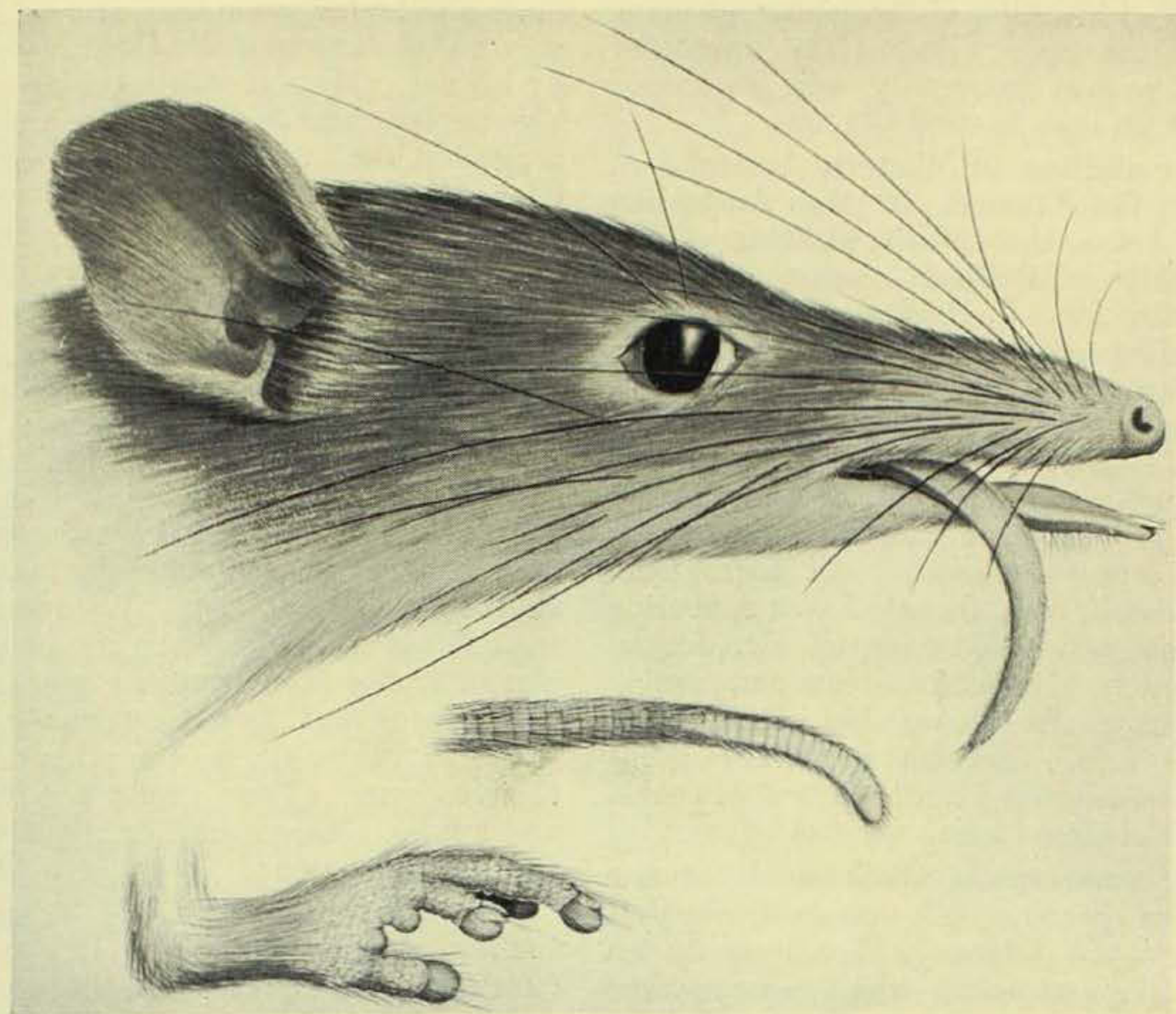

\begin{abstract}
Head of the Honey Mouse. Note the long lower incisor teeth projecting from the lower mandible or jaw. The lower lips are provided with upstanding flanges which close within similar ones above, thus preventing a leakage of honey. The tongue is clothed with bristles and serves as a brush.

Depicted also is the tail-tip and the foot. The bare skin under the tail-tip prevents it slipping when curled round twigs, and the curious foot has a widely separated, thumb-like great toe which also helps the climber.
\end{abstract}

[A. R. McCulloch, del. Block by courtesy of "The Australian Zoologist."

bristles as the tongue is thrust out for a fresh load. Most children and many grown-ups know that eating honey is a sticky operation requiring some care, and so nature has provided the Honey Mice with long flanges of flesh along their lower lips on each side which interlock with similar flanges above; in this way the partially closed mouth forms a tube to convey the honey sucked in by these floral vacuum cleaners, and prevents a leakage of the juicy food. The action is much the same as drinking ice cream sodas through a straw and, in this way, the whiskers of the fastidious little creatures are kept in perfect order.

Even to Honey Mice, as to humans, too much honey appears to have a cloying effect and as it does not constitute the sole diet, attempts to keep the mice in captivity have always failed after awhile. Quoting $\mathrm{Mr}$.
Gilbert's notes, Gould wrote in his Mammals of Australia as early as 1863 of a specimen in captivity :- " It is strictly nocturnal, sleeping during the greater part of the day and becoming exceedingly active at night. When intent upon catching flies it sits quietly in a corner of its cage, eagerly watch ing their movements; when a fly was fairly within reach, it bounded as quick as lightning and seizing the fly with unerring aim, retired to the bottom of the cage and devoured its prey at leisure." When eating insects the mice sit fairly erect, holding the wings of the moth or beetle in their forepaws while eating the plump bodies, then they throw away the wings, legs, and head. The artificial food given to Mr. Gilbert's captive was sopped bread sweetened with sugar, and every morning the sop was completely honeycombed by 
the repeated insertion of the mouse's tongue to collect the sweet syrup. The tongue of this captive was frequently seen protruded for nearly an inch beyond the nose.

While collecting in Western Australia in 1922 for the Trustees of the Australian Museum, I was, through the kindness of Mr. H. L. White of Belltrees, Scone, placed in touch with Mr. F. Lawson Whitlock of Tudor Siding, on the Albany-Denmark Line, who had recently forwarded a specimen of the Honey Mouse to Mr. White. Upon Mr. Whitlock's advice I gathered up stores and gear and set out for the home of Mr. David Morgan, in the same district, whence the specimen originally came. All there were kindness itself, and, though I was expecting to camp out and cook for myself, Mr. Morgan established me in a comfortable room, passing my rations on to the capable hands of his hospitable wife. This was a matter of great relief to me because I am the worst of cooks, and it left me free to seek my small quarry.

The little marsupials, whose scientific name is Tarsipes spenserae, are known throughout the district as "Honey Mice," surely an excellent popular name, when one considers the habits recounted here. I hunted acres of the countryside, peering under and through "Grass Trees," the foliage of Bottle Brush, and the local "Ti Tree " in search of the mice or their nests, which are said to be small round grass-nests, like those of dormice, placed amongst the thinner branches of $\mathrm{Ti}$ Trees or Paper Barks. Various trapping methods were tried with baits composed of oatmeal and honey pellets or pure honey, but without success.

Failure was not surprising, all accounts confirming Mr. Morgan's statement that the mice visit areas periodically according to the flowery food supply, and that they are but rarely seen except when brought in by cats as trophies of the chase. Fortunately other interesting specimens were secured, and $\mathrm{Mr}$. Morgan, though in the midst of a busy farming season, lent every assistance, including a horse which enabled the area of search to be extended ten miles coastward to the Leeuwin, where my kindly volunteer guide and I stood to watch the sun set west of Australia.

Such is collector's luck, however, that, a few months after my return to Sydney, the Honey Mice visited Mr. Morgan's home once more and he has since sent over twenty adult mice to the Museum, all of which were caught by his cat. He also wrote telling me he was keeping two mice in a large cage and in reply I suggested the making of observations and a trial of various foods. As a result, Mr. Morgan forwarded some very interesting notes, which form a tribute to his interest and patience, and of which the following are but brief quotations.

" Each of the two pairs we kept at separate times died in about six weeks; they received every possible care, were lively and not timid, taking food supplied, but as they died run-down and emaciated we decided not to keep any more, believing it impossible to keep them in eaptivity. We supplied them with bee's honey on which they gorged; alongside the honey-pot we placed a jar of fresh water and they took honey and then water in the same manner, by darting out their tongues. They would not drink milk, and apples, either sound or slightly decayed, were hardly touched.

"We also supplied a big bunch of blossoming native shrubs each day which they climbed over, sucking the honey from the flowers with their tongues. They were very fond of the Bottle Brush, though this appeared to us to contain nothing, and seemed to run all the spikes through their mouths, turning them down and nosing all about the cone of the flower as if in search of gum, pollen, or some other matter required by them. In this locality some variety of shrub is in bloom all the year round, enabling the Honey Mice to secure a continuous supply of honey and pollen.

They seem to be nocturnal, judging by the time they were most active in the cage, and because the cat brings them in at dusk, or later, or in the early morning. In climbing over leaves and twigs they hold on with their tails, being quite at ease feeding upside down if necessary, and the weakest twigs seem to bear them quite easily. They roll themselves into a ball when sleeping, feet, legs, head and tail being tucked in so that all extremities disappear."

The interesting information gained is sufficient proof that Mr. Morgan's attempts to keep the elusive little animals alive were not in vain, and it is not surprising that it was impossible to keep in captivity animals so unique both in constitution and diet. 
Though he concluded that the mice fed only upon honey and pollen, they are known to eat soft-bodied insects, and doubtless it was the lack of this phase of their menu, coupled with gorging upon refined honey and the absence of freedom and exercise which proved fatal.

Attention abroad was first drawn to these unique creatures early in 1842 in connection with specimens in the Paris Museum, but the description by the French naturalists was not published until.June : meanwhile the British Museum received specimens which, several months earlier, were given the scientific name which stands for all time. Reading between the lines, one can imagine the keen rivalry of the English and French authors for the honour of naming the quaint marsupial, the victory of the former causing a brief upheaval of the entente " zoologicale."

So unique is the Honey Mouse amongst marsupials that it occupies a sub-family entirely to itself, that is, a sub-section of the big family which contains the common, flying, and ring-tailed possums, possum-mice, and the native bear. Its dentition has degenerated from the original ancestral form in becoming adapted to a pulpy and honey diet: all the teeth are frail and semitransparent, the molars being represented by a varying number of teeth of no definite form and the lower incisors are thin and needlelike. At one time this primitive appearance of the dental arrangement was regarded as a retention of the dentition of very primitive ancestral forms. Latterly, however, most authorities consider that the teeth have retrogressed from the normal ancestral form and undergone special development as a result of adopting the honey-eating habit.

The ancestors of the Honey Mice were doubtless entirely insect eaters, having strong teeth and eating hard-bodied insects with ease : gradually this fare was supplemented with blossoms and honey, and, as the proportion of honey-food increased, the teeth were correspondingly modified, so that to-day only the soft bodies of insects can be masticated. Mixed up in the basins of the flowers the honey and pollen must constitute a delightful sort of custard trifle to the mice, with small beetles and flies replacing currants and raisins and thus maintaining the penchant for insects.

The mother mouse requires her paws and tail for the strenuous climbing existence, and

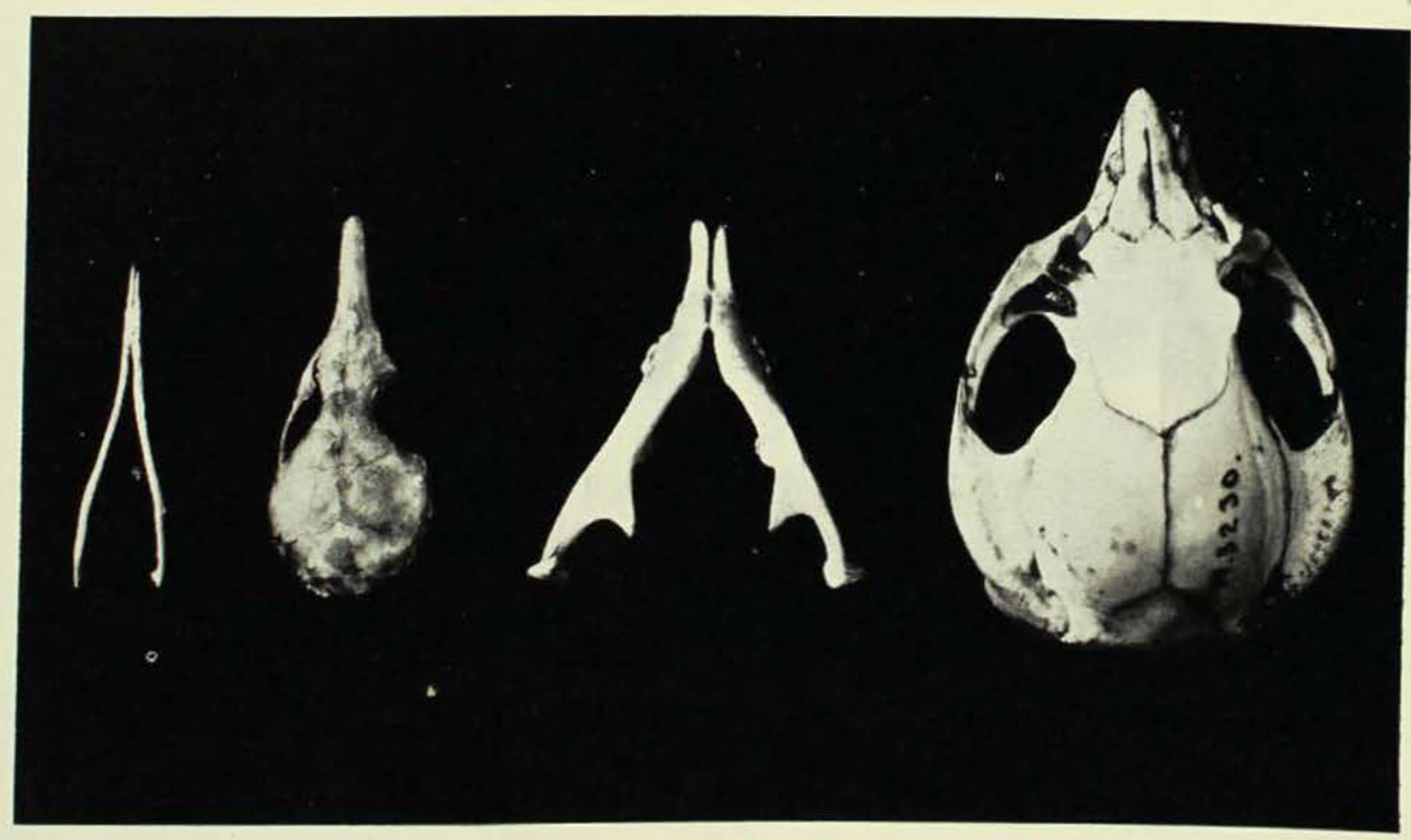

The skull of an adult Honey Mouse compared with that of a small Flying Opossum (Petaurus breviceps) which belongs to the same family of marsupials. Note the fragile, bird-like structure of the former which has been evolved owing to the gradual adoption of a soft diet. Though the skull of the opossum is but little longer than that of the mouse, it has retained the strong broad structure and crushing jaws and teeth associated with its harder food.

[Photo.-G. C. Clutton. 
the young, varying from one to four, are carried in her comparatively deep pouch until they become too large and have to be left at home in the nest. Accounts of the nest of the Honey Mouse differ, some stating that the grass-nests are built in the taller trees, while, according to another the nests of

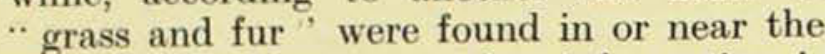
ground. Further interesting information is to hand from Mr. L. Glauert of the West Australian Museum, who writes that a collecting party from his Museum, while on the Stirling Ranges, " discovered a family of three young Honey Mice sound asleep in the deserted nest of a Tawny Crowned Honey. eater (Glyciphila melanops)" ; the bird's nest was in a low bush, about six inches above the ground. Apparently the mice, like many humans, are lazy builders and sometimes prefer to look around for a house " to let."

As they are dependent upon the native flowers, the advance of settlement with its periodical burning off, and the introduction of cats and other enemies, in addition to native ones, must seriously threaten the future of these fascinating marsupials, which have hitherto survived from ages beyond human ken.
It is reassuring to hear from Mr. Glauert that the mice are still fairly plentiful over an area of about 12,000 square miles, and that at the end of 1923 the West Australian Government was about to proclaim the Stirling Ranges a sanctuary for the native fauna. Let us hope that these ranges may prove a veritable stronghold for the Honey Mice, and that the flowers may not miss their spring. cleaning from the brushy tongues for many generations to come.

Apart from their scientific importance, as insect-eaters the mice are indirectly allies of man, as are so many of our native animals. Being a museum worker I am always glad to appeal for the protection of our native animals, for though such workers are often supposed to care only for dry-as. dust skin and bone, yet the more dead animals we see, the more we wish to see alive. Therefore, let us unite in establishing adequate national reserves for our hunted creatures, and, though unlike Peter Pan we have to grow old and cannot always believe in fairies, our belief in the furred fairies of the Australian bushland may prevent a gradual fade-out of our fauna and protect them for posterity.

\section{Notes and News.}

To fill the vacancy on the Board of Trustees caused by the resignation of Professor Sir Edgeworth David, Mr. E. C. Andrews, B.A., F.G.S., Government Geologist of New South Wales, was elected on 4th July. Mr Andrews, who is one of the foremost living geologists, is a member of the Washington Academy of Sciences, and an Associate Editor of Economic Geology (Yale University). He has always taken a leading part in any scientific movement, having been closely associated with the PanPacific Science Congress since its inception : he was elected permanent Honorary Secretary of the Australasian Association for the Advancement of Science in 1921, and still holds that position.

By the death of Mr. John Vernon, announced in our last issue, a vacancy was created on the Roard of Trustees. This was filled on August 1st by the election of $\mathrm{Mr}$. Octavius C. Beale, Governing Director of
Beale \& Co. Ltd., piano manufacturers. Mr. Beale was the first President of the Associated Chambers of Manufacturers of Australia. He was a member of the New South Wales Royal Commission on the decline of the birth rate, and, in 1909, was appointed a Royal Commissioner to enquire into secret drugs and preparations.

Mr. W. H. Wooster, a veteran worker in zoology who has specialised in the Bryozoa, has presented to the Museum his fine collection of Bryozoa slides. The collection consists of 795 slides, the material having been gathered in all the States of Australia during the long period of forty years, and many of the species have been named or identified by the eminent bryozoologist Dr. B. H. MacGillivray of Victoria, with whom Mr. Wooster co-operated for several years. This is an exceedingly valuable donation, and the Trustees are greatly indebted to $\mathrm{Mr}$. Wooster for his generosity. 


\title{
The Honey-Eating Marsupial Mice of Australia.
}

\author{
By Ellis Le G. Troughton.
}

$\mathrm{T}^{\mathrm{H}}$ HERE must be very few bush-lovers who do not know our honey-eating birds. Even the smallest school child has probably watched them flying amongst the flowering shrubs and perching, sometimes head downwards, to thrust their long bills and brush-like tongues into the blossoms in search of the honey, pollen, and small insects contained therein.

On the contrary, there must be very few Australians indeed who have even heard of the tiny marsupial mouse-like creatures which inhabit one small corner of our vast continent and emulate the well known flowerforaging habits of the birds. Once ranging as far north as the Swan River about Perth, these furry honey-eaters are apparently becoming gradually restricted to the southwestern corner of Western Australia. So shy and elusive are they, that, even where they are plentiful, but few people have seen them as they go swinging with blithe agility from twig to twig, thrusting their slender snouts and long brushy tongues into the blossoms. Alas, as settlement increases, the time seems near when there may be no living representatives of these unique creatures to occupy the queer niche which the process of evolution has fashioned for them within its fabric.

Flight would seem to be essential to flowerfeasting when you consider the bees, butterflies and birds. Bats can fly as long and as easily as birds, and we have several marsupials in Australia, belonging to the same family as the Honey Mice, which have skinny membranes stretching between the fore and hind limbs enabling them to take gliding leaps from one branch to another, and even from tree to tree. Yet the marvellous workings of evolution failed to provide the Honey Mice with any such aids to aviation as might have been expected in marsupials dependent upon the flowering trees for so much of their menu. Therefore as honey-eaters the little mice are handicapped in comparison with the birds. But by way of compensation, and Nature certainly has a habit of balancing things, the Honey Mice are provided with tails which are much longer than the head and body combined, and which have, on the under- surface, near the tip, a bare patch of grooved skin. These tails are prehensile, with a clinging power such as is found in the Ring-tailed Opossums and many kinds of monkeys; the slender tips curl and cling around the twigs, and their owners are able to suspend themselves above the blossoms, or to swing away gaily in search of fresh honeypots.

Of small size and slender form these marsupials are admirably adapted by nature to their tree haunting life; their bodies are about the size of the house mouse one often sees trapped in the pantry, but the pantry fellow is a rodent, and was brought to our country long ago by ships, whereas the Honey Mouse is a marsupial and much more handsome as befits a native of Australia.

The fur is short and coarse and the general colour is greyish-brown above, with a dark brown stripe along the middle of the back from head to tail-root, and a lighter brown stripe on each side of the middle one. There is a reddish tinge on the flanks and shoulders and the under parts are buffy-grey. The snout is very long and tapering and the eyes are placed very close together, about midway between the ears and the nose-tip.

There are five digits on the fore and hind paws and the great toe of the long hindfoot is freely opposable in a thumb-like way to the other toes, the foot thus supplementing the tail as a gripping organ for these arboreal acrobats. The toes are apparently better suited to grasping twigs than for scaling tree trunks, as the nails do not project beyond the toe-pads, being mostly embedded in the fleshy parts.

The tongue, however, presents the most striking evidence of an adaptation to the unusual feeding habits of the mice, being long, slender and very protrusile, so that aided by the long and tapering snout the tongue can be thrust deeply into or amongst the bells of flowers. The upper surface of the tongue is thickly coated with short erect bristles, which are longer in front, and form a lengthened tuft at the tip. There are pronounced ridges on the palate which are so shaped as to imply that they act as combs to scrape the sticky food from the 


\title{
Dinosaur Eggs.
}

\author{
By C. Anderson, M.A., D.Sc.
}

$\mathrm{I}^{\mathrm{N}}$ a previous issue of this Magazine* reference was made to the remarkable discovery of twenty-five dinosaur eggs by the Third Asiatic Expedition of the American Museum of Natural History, during its exploring operations in the Gobi Desert of Mongolia. Through the courtesy of the authorities of the American Museum, and the good offices of Dr. W. K. Gregory and Mr. Walter Granger, we have received a cast of one of the eggs discovered in the Djadochta formation at Shabarakh Usu, near the eastern end of the Altai Mountains,

* The Australian Museum Magazine, Vol. II. No. 1 January, 1924 , p. 11. so that visitors to the Australian Museum may now see for themselves what theseten million year old eggs were like.

It is well known that some reptiles produce their young alive, while others lay eggs which are left to be hatched by the heat of the sun. When the reptiles belong to groups which have long been extinct we are often left in doubt as to their mode of producing young, and have to rely on the evidence of structure as revealed in their petrified bones, or, rarely, the evidence may be direct, as when the actual eggs are found fossil. It had long been suspected that some dinosaurs at least were oviparous, and now the question is settled as regards one species at any rate, presumably

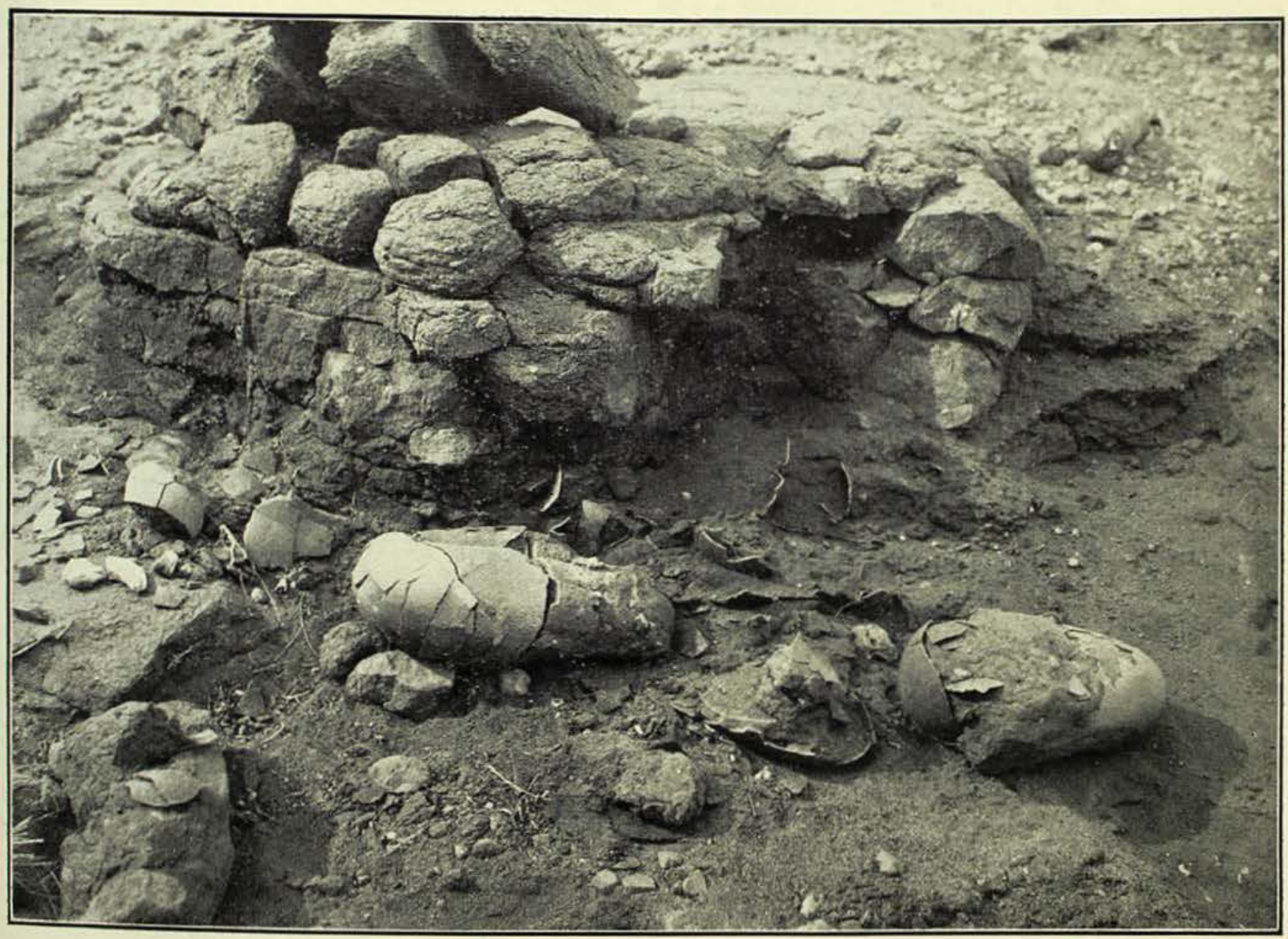

A "nest" of Dinosaur eggs found in the Gobi Desert; the original of the cast in the Australian Museum is in the centre of the photograph.

[Courtesy American Museum of Natural History. 
the primitive horned dinosaur, Protoceratops andrewsi, a new genus recently described by Mr. Granger and Dr. Gregory.

The eggs are from six to nine inches in length, the specimen of which we have received a cast being six inches long and nearly three inches in diameter. The texture of the shell was well preserved in the original, which is seen about the centre of the fine photograph showing the eggs in the " nest." just as they were discovered; for this photograph too we are indebted to the American Museum of Natural History. The shell is cracked in various places, and has suffered some distortion; the interior is filled with fine red sand.

The Gobi Desert, where this interesting find was made by Mr. Roy Chapman Andrews, leader of the Asiatic Expedition, affords ideal conditions for the entombment and preservation of animal remains. Here we have a continental mass, raised three or four thousand feet above sea level. Rainfall has probably never been heavy on the plateau, and the dryness of the atmosphere, the absence of large rivers, and the prevalence of fine sand or dust which has covered the bones and eggs with a protecting mantle of windborne material, were important factors in preserving for us these extremely interesting relies of a bygone age. When the Djadochta beds were forming the climate was probably semi-arid, as indicated by the fine reddish sand, which is evidently of wind origin, deposited in shallow lakes or flood plains. The beds are about five hundred feet thick and have been carved into cliffs, at the base of which the dinosaur remains were found. One very interesting and important feature is that all stages of Protoceratops have been found, from the small skeleton contained in the egg to the full grown animal.

The American Museum, the American Asiatic Association, and Asia, which are co. operating in the exploration of this fascinating region are to be congratulated on the success already attained, and there is no doubt, that, when the large collections obtained are fully examined and described the scientific results will prove to be of the very highest value in the elucidation of the evolutionary history and the migratory route of many groups of animals.

It is announced that after complete examination and description, surplus eggs will be sold at a price of about $£ 400$ each, the proceeds to be used to defray the expenses of the expedition.

This Museum is already under a deep debt of gratitude to the American Museum for many courtesies and much generous help, and this interesting gift is another example of the fine spirit of co-operation which animates that great institution.
Among recent visitors to the Museum may be mentioned Dr. H. C. Busing, ConsulGeneral for Germany, who came to inspect the Turnwald New Guinea collection; $\mathrm{Mr}$. W. H. Chen, legal adviser, Eureau of Foreign Affairs, Shanghai and Nanking; Father Jos. Lorks, Catholic Mission, Alexishafen, New Guinea, who wished to consult our library of works on New Guinea; Mr. H. D. Skinner, B.A. of Otago, New Zealand, President of the Anthropological Section of the Australasian Association for the Advancement of Science, Adelaide meeting; Mr. Briggs, Nairobi, with a party of friends ; Mr. H. C. Cardew, Department of Native Affairs, Mandated Territory, who presented two large fish figures from New Ireland, and weapons and canoe from Aua; Major E. A. Le Souef, V.D., Director of the Zoological
Gardens, Perth, President of the Agricultural Society of Western Australia, and Associate Lecturer on Veterinary Science in the University, Perth, who was specially interested in habitat groups.

"Lighten our darkness " is a text that can aptly and quite conscientiously be applied to the position of affairs in part, at least, of our galleries. Lack of funds and stringency of the public purse have resulted in many of our exhibits being consigned to an almost sepulchral gloom. Adequate lighting is a prime essential in any museum, and the hope is now expressed that a considerate Minister will see the way to help us out of a difficulty that at present is productive of a criticism and public censure of which the Trustees are not deserving. 


\title{
Curious Habit of the Hedgehog.
}

\author{
By F. MoLL.
}

\begin{abstract}
A legend has long been eurrent in Europe that the hedgehog is sometimes in the habit of collecting fallen apples, pears, plums, and the like by rolling upon them. Mr. Miller Christy has investigated this legend (Manchester Memoirs, 1918-19 and 1922-23) and comes to the conclusion that it has a basis in fact. The following account by a resident of Sydney, who was an eyewitness to the happening, is very similar to one quoted by Mr. Christy, but it differs in details and supplies additional evidence for the truth of this ancient belief.-EDitor.
\end{abstract}

$\mathrm{T}^{\mathrm{H}}$

EE following curious incident came under my observation about twentysix years ago, when, as a lad in my early teens, I was living with my parents in Central Europe.

We had a little orchard on a steep hillside, and in it grew an old pear tree which produced a very delicious small fruit. We were in the habit of allowing the ripe pears to fall from the tree, collecting them each morning. At the particular time of which I speak, potatoes had been planted around the pear tree, and these had been nicely " hilled," so that the fallen pears would collect between the rows. One morning my father went at daybreak as usual, to collect the fruit that had fallen during the night, but found only a few. He did not attach much importance to this, but when he had the same experience on the two succeeding mornings, he suspected a thief. To eatch the marauder, he went to the orchard next morning before dawn, and stationed himself near the tree to watch. As the grey of the morning was beginning to appear, he heard a slight rustle repeated several times, and, presently, he saw an adult hedgehog coming up between the rows of potatoes close to the tree. The little rogue went a short distance up the slope above the tree, lay down between the rows, and rolled down past the tree. In this manner he collected quite a number of the soft pears on his back, his needle-like spines spearing them effectively. When he had repeated this performance several times, he trotted off to a hole in a wall of loose stones. My father, who was a lover of all animals, did not disturb the little creature, but at breakfast time he told us that he had discovered the thief, and promised that if we would rise very early next morning, he would show us where our much relished pears were going.
Next morning my brother and myself accompanied my father to the orchard before daybreak. After some time our little friend appeared and repeated his performance. We saw him roll down at least six times, after which he had a fine load of about two dozen small pears. He then went off to his lair in the stone wall, but in less than five minutes he returned "empty." He appeared to know exactly where he had left off, as he next devoted himself to the succeeding rows, and loaded up once more. This time we followed him to his hole, but could not reach him with our hands, and my father would not allow us to use a stick. He did not re-appear, as no doubt we had frightened him. After this we collected the fallen pears either late at night or before dawn, as my father considered that the hedgehog had had his share.

There were always a number of these interesting little animals round our home, and several times we uncovered their winter quarters in the spring, finding heaps of plum stones and remains of pears. These, no doubt, represented the residue of the winter store which had been collected during the late autumn and early winter. The animals seemed to collect only fruit suitable for "evaporation," for the only fruit stonesfound were those of prune plums, although the orchard contained other kinds as well, and the particular pears they seemed so fond of were those my mother used to evaporate. It appears as though these clever little animals collect a store of such fruits as will dry up naturally, instead of rotting, and so accumulate a reserve supply of food for the winter months. If it is instinct that moves these creatures to act so wisely, then it is difficult to draw the line between instinct and intelligence. 


\title{
Radium and the Age of the Earth.
}

\author{
By T. Hodge SMITH.
}

$\mathrm{T}^{\mathrm{H}}$ HE problem of the age of the earth has been of absorbing interest to scientists of all ages and many have been the attempts to solve it. There has been a considerable discrepancy between the time estimated by geologists and biologists on the one hand, and by physicists and mathematicians on the other. The former from a study of sedimentation, erosion, and the evolution of life, have calculated the age of the earth to be much greater than that computed from purely physical evidence. The reason for this discrepancy is to be found in the fact that scientists knew little or nothing of the earliest history of the earth, and furthermore they had no knowledge of the interior structure of the earth. Of necessity they had to make assumptions which, of course, were the very foundation upon which they built the superstructure of their hypotheses, and, no matter how accurately they built this superstructure, if the foundation is faulty then the whole building must fall to the ground.

The discovery of radio-activity by Becquerel as far back as 1896 opened up new fields of research, the result of which, in a very surprising manner, has thrown new light on the subject and seems likely to settle the long standing argument between the two schools of thought.

Uranium and thorium are the two parent elements which give rise to radio-activity, but, in considering the age of the earth, we need deal only with the former. The definition of an element given in most textbooks is that it is a simple substance, out of which no other two or more essentially differing substances have been obtained. It would seem that we will have to modify this view somewhat, for the element uranium has been found to break up or decompose in eight well marked stages. In the course of this decomposition radium is formed, but the final stage is lead which is the only one that is stable. This decomposition is caused by the uranium giving off helium atoms. When one atom of helium is given off the first stage is reached and ionium is formed. This in turn gives off another atom of helium and the second stage, radium, is reached, and so on until lead is formed, which so far as we know, does not undergo any further change. Thus a uranium mineral may contain all the eight substances which are continually being formed and decomposed simultaneously, except of course the lead. The helium is also stable, but unfortunately, being a gas, it escapes far more readily than lead.

The rate of decay of uranium into lead is a known and constant quantity, unaffected by high temperatures and pressure, and independent of the state of chemical combination of the uranium salt. That is to say, the rate of decay of uranium in uranium oxide is the same as in uranium sulphate. It was only in 1905 that Boltwood first suggested that lead was the final product of the decay of uranium. Later research has revealed the fact that one ton of uranium yields one hundred and ninety-six grains of lead in one million years.

If a chemicial analysis is made of a mineral, the amount of uranium and lead present in that mineral can be determined, and by a simple proportion sum the age of the mineral is known at once. But if ordinary lead had formed with the mineral as an impurity, this determination would be quite wrong. However, Nature has been particularly kind to us in this respect, for the lead derived from uranium is more dense than ordinary lead, so that the lead obtained by analysis has to be tested for its weight, or more strictly its molecular weight, and corrections made accordingly.

From the earliest times of the earth's history great masses of molten rock have intruded sedimentary rocks or have been poured out on the surface of the earth. On cooling the molten material solidifies and various minerals crystallise out. If a uranium mineral happens to form there is at once a clue to the age of the rock mass itself. Thus from the age of a mineral is derived the age of the earth, or perhaps more correctly the age of the oldest known rocks.

Sedimentary rocks often contain fossils and by the fossil content of these rocks and their relative vertical position, geologists have been able to give their relative ages. 
With this knowledge they have been able to divide the history of the earth into a number of well marked periods. The accompanying table gives the major periods of the earth's history and also the time occupied by these eras as estimated from geological, physical, and chemical evidence.

\begin{tabular}{l|l|r|r|r}
\hline \multirow{2}{*}{ kra. } & & \multicolumn{3}{|c}{ Time, in million years, } \\
based on
\end{tabular}

From this table it will be seen that there is nearly as great a discrepancy between the estimates based on the evidence of radioactivity and those based on geological evidence as between the latter and that based on physical evidence. The assumptions of the physicists are now considered to be erroneous, and though their estimate was never accepted by geologists, nevertheless they were influenced by that estimate in so far as they adopted minimum rather than maximum values.

It is of interest to note that at least one geologist remained uninfluenced by this estimate for, in 1896, Goodchild - basing his calculations chiefly on the rate of sedimentation - estimated time values of the various geological eras which agreed substantially with those based on the evidence of radio-activity.

\section{Museum Needs and Assistance.}

Quite recently an appeal to the public on behalf of the Museum was made through the columns of the Sydney Daily Telegraph. The disabilities and disadvantages under which the Museum labours were stressed, lack of funds for prime essentials within the institution's four walls, for urgent collecting expeditions, the urgency of which increases as time moves forward, and in numerous other ways which have been emphasised time and again within these pages.

A comparison with the patronage accorded to museums in the United States was made. Instances were given of lavish endowments to certain institutions there and also of the numerous small amounts which, in their hundreds and thousands, make an amount with which something tangible may be done. The American Museum of Natural
History, New York, boasts some 7,000 subseribers of amounts varying from 50,000 dollars to 10 dollars and 3 dollars, the greater number of which fall in the last two divisions, distinctly showing that not all assistance is from the captains of industry or brokers of Wall Street.

As a result of this appeal, Mr. Robert C. Dixson presented the sum of $£ 25$, enabling the Museum to acquire a valuable ethnological collection made in the South Seas many years ago and containing many items hitherto imperfectly, or not at all, repre. sented. Mrs. Edith Debenham also forwarded a cheque for $£ 1$ ls., expressing her appreciation of the Museum's educational movements. The community's thanks are due to these donors for their public spiritedness. 


\section{Notes and News.}

The accompanying graph depicts in a very lucid manner the growth of public interest in the Australian Museum, its treasures, and its doings. The efforts made to eater for the public are many and have been enumerated frequently in these columns; that they are appreciated is evidenced by the records of attendance. It is becoming realised more and more that even if one cannot travel to distant lands, yet there is no need to be in total ignorance regard. ing them. The birch canoe of the American Indian and the model of the lakatoi, or Papuan trading canoe, the bison and the Indian gaur, the polar bear and his cousin from the Rockies, the coral pool exhibit and Hawaiian group, the Antaretic and fruit bat groups, all convey lessons and knowledge of parts distant and remote from one another.

The comparison of attendance figures is striking. For the period January to September, 1923, the attendance was 159,967 as against 205,930 for the similar period this year. Could anything speak more eloquently than these figures?

Ever ready to serve the public interest, the Trustees of this Museum have, with the co-operation of Farmer and Co., Ltd., been broadcasting natural bistory stories of interest to the young, and other items of Museum interest. Through the agency of wireless it has thus been possible to get in touch with some hundreds who, through distance and other reasons, have not been able to avail themselves of all the good things the metropolitan resident enjoys. Such talks as these are heard far beyond the Commonwealth, and the awakening of a live Museum interest may some day bring much gain to the Australian Museum. Who knows?

Their Excellencies the Govenor-General, Lord Forster and Lady Forster, accompanied by Lieut. W. Seymour, A.D.C., R.N., visited the Australian Museum on September 29th. They were met by Dr. T. Storie Dixson, President of the Board of Trustees, Dr. Anderson, Director, and Mr. W. T. Wells, Secretary. The Vice-Regal visitors were particularly in. terested in the ethnological collection after their recent visit to the Mandated Territory of New Guinea. Mr. W. W. Thorpe, ethno. logist, conducted the party during the inspection, and explained the interest and significance of many of the exhibits. 


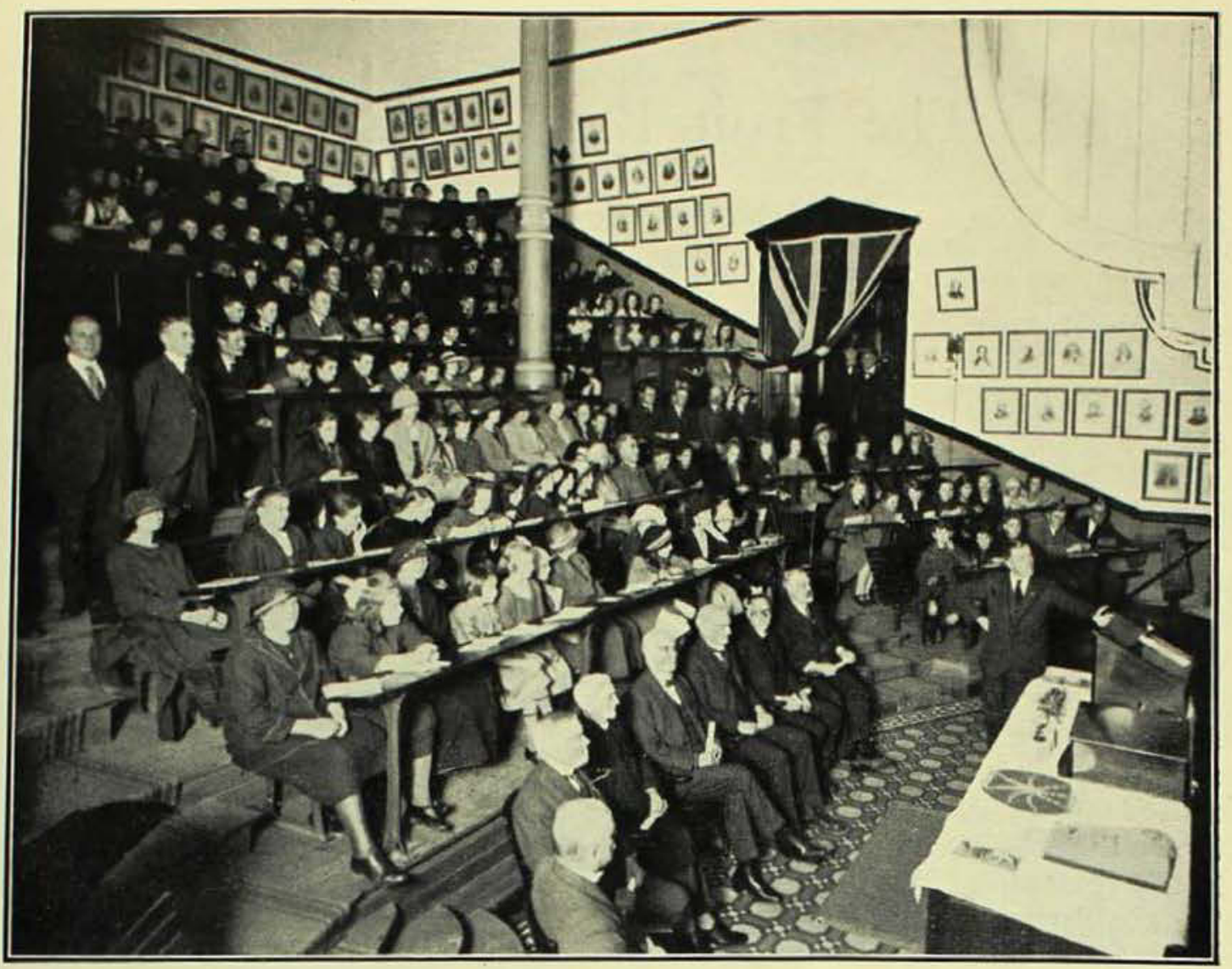

Lecture to School Ghildren by Mr. J. R. Kinghorn on July 22nd. See accompanying paragraph on this page.

Photo.-A. R. MeCulloch.

On July 22nd the Hon. A. Bruntnell, M.L.A., Minister for Education, accompanied by Mr. S. H. Smith, Director of Education, visited the Australian Museum. They were received by the President, Dr. T. Storie Dixson, Messrs. F. A. Coghlan, E. Wunderlich, F.R.A.S., Sir William Vicars, Sir Charles Rosenthal, Dr. C. Anderson, Director, and Mr. W. T. Wells, Secretary. The occasion was a lecture, one of a series, to school children by Mr. J. R. Kinghorn, C.M.Z.S. For some time past such lectures have been a regular feature of the Museum's activities, and are much appreciated by the young folk who journey in many cases from distant suburbs. In this particular instance the lecturer dealt with marine life, and explained the why and wherefore of many queer creatures of the sea - fish, star-fish, sea urchins, anemones and frequenters of the beaches. A cinema film by Mr. Allan R. MeCulloch illustrated many of these in life.

Dr. T. Storie Dixson, President of the Board of Trustees, attended the Adelaide meeting of the Australasian Association for the Advancement of Science as the representative of the Australian Museum, and also took part in a combined conference of Australasian Museum representatives dealing with matters of common interest.

On September 10th, Mr. E.A. Briggs, M.Sc., displayed the cinema film taken by him during his recent visit to the Mandated Territories, New Guinea, as a member of the expedition in quest for oil there. Present were Dr. T. Storie Dixon, President, and Mr. E. Wunderlich, F.R.A.S., and Professor Launcelot Harrison, B.Sc., B.A., Trustees, Professor Grafton Elliot Smith, and Mr. S. H. Smith, Director of Education. The film showed pottery-making, house construction, dancing and other native arts.

On September 20th Mr. J. R. Kinghorn lectured to Farmer's "Children's News" Radio Birthday Club on bird-life. The audience of about four hundred juveniles was intensely interested. 


\title{
The Fruit Bat Group.
}

\author{
By E. Le G. Troughton.
}

$\mathrm{O}^{\mathrm{F}}$ recent years the galleries of our Museum have been brightened by the construction of habitat groups presenting the animals in their natural surroundings or, as it is termed, habitat.

An opportunity to prepare a Fruit Bat Group was awaited, but, as these creatures are mainly nocturnal, it was difficult to secure adequate numbers. However, sometime ago a colony of several hundred established themselves in the Norfolk Island pines adjacent to the venerable "Wishing Tree" in the Sydney Botanic Gardens, and from this colony about thirty specimens were collected, many of which are used in this group.

The scene is typically Austra. lian, such as might be found along the valley of the Nepean River, and the bats are shown at the restless hour when the setting sun casts a glow from the west and the rising moon struggles to make its rays effective. It is at this hour that the bats awaken to scream and squabble before flying away to the nearest feeding ground of fragrant flowering gums or orchards, where great damage may be done.

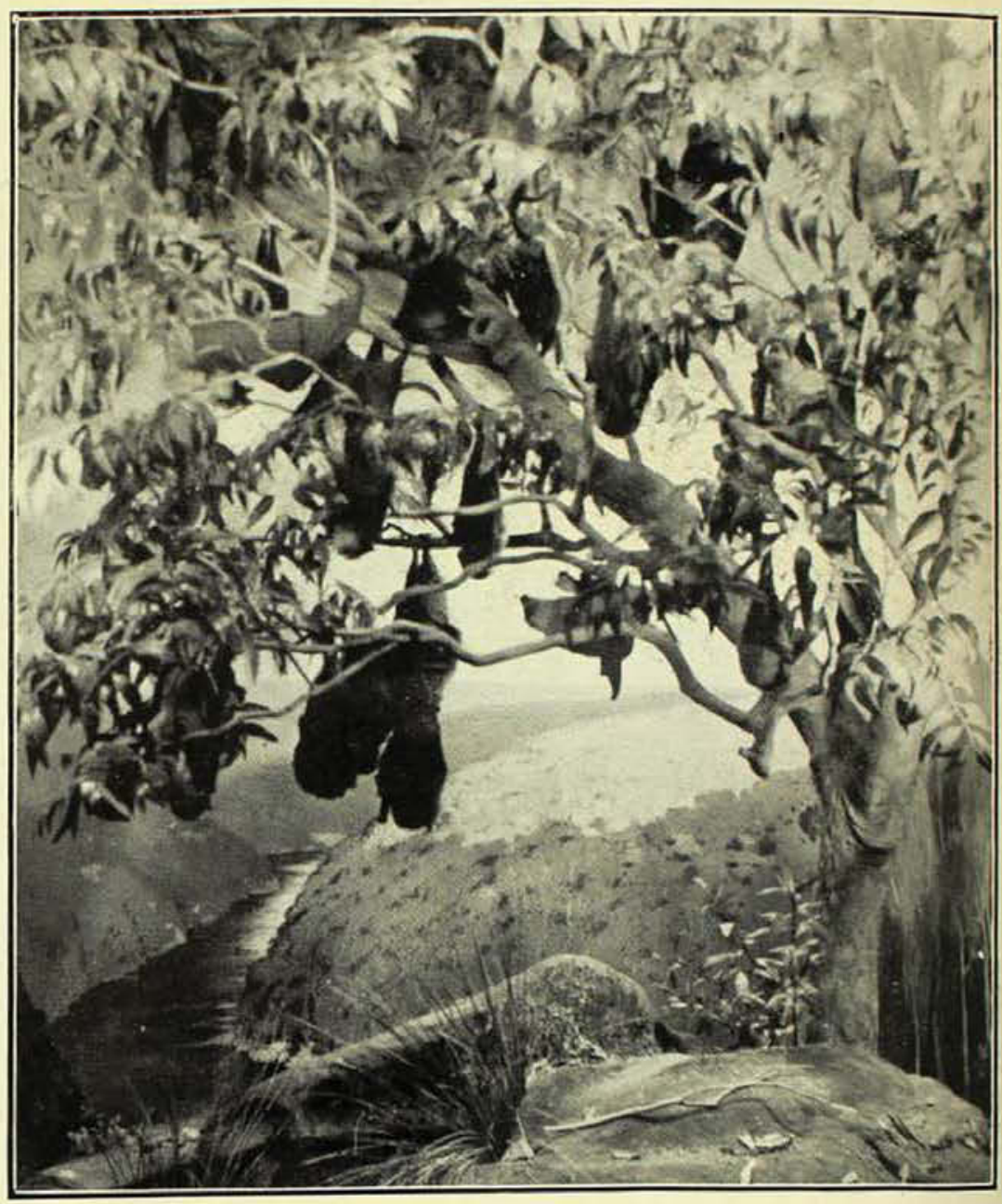

A habitat group of the Grey-Headed Fruit Bat, or "Flying Fox" (Pteropus poliocephalus), recently installed in the Australian Museum.

[Photo.-G. C. Clutton.

The exhibit, which has evoked much favourable comment as regards its artistic treatment and lighting effects, was designed by Mr. H. S. Grant, who was assisted in its con. struction by Mr. J. H. Wright, taxidermists, whilst the background was painted by Mr. A. Gallop. A new method in construction was successfully employed, in which the inside of the case was modelled in papier mâché, enabling the corners to be rounded and the ceiling domed, the whole being in

one piece, upon which the background was painted.

The group, despite the fact that it has been on view for a few weeks only, has been a centre of attraction and some hundreds have seen it. In the January-March issue of The Australian Museum Magazine there will appear a more detailed account of fruit bats and their habits, accompanied by illustrations. 


\section{Lecture Notes.}

$0^{*}$ N July 10th Mr. Anthony Musgrave delivered a lecture entitled " Lord Howe Island, the Madeira of the Pacific," in the Museum lecture hall. The lecturer, who recently visited that " Paradise of Palms," dealt vividly with the beauties and charms of the island and many of the biological problems which confronted the naturalist due to the upsetting of the balance of nature by the rats which had invaded that hitherto undisturbed sanctuary. Coloured slides prepared by Mr. Musgrave, showed many charming features of the natural history of the Island, the birds of the adjacent Admiralty Islets and phases of the Kentia palm seed industry, and a fascinating cinema film by Mr. A. R. McCulloch depicting the coral reef and its inhabitants, revealed to the large audience many facts about the island of which they had been previously unaware.

The entire seating accommodation being occupied, and many being unable to secure admission the lecture was repeated - the hall again proving inadequate.

Taking for his subject " Nests of some Australian Birds," Mr. J. R. Kinghorn on August 14th lectured to an overflowing audience. The evolution from the primitive resting-place on the bare ground to the elaborate homes of the African Grosbeak and the cunningly contrived nest of the little Grass Warbler, a few leaves beautifully sewn together by grass thread, was elaborately dealt with. Some freak nests were exhibited, some constructed in tin cans, others built with oddments of feneing wire and so on, but probably the most up-to-date of all was one recently presented by $\mathrm{Mr}$. W. T. Watkin Browne, F.R.M.S. This was composed entirely of "wireless" wire which the donor had swept from his workshop. A feature of the lecture was a beautiful cinema film of bird life on Lord Howe Island. A plea was made for the preservation of bird life and the sanctity of nests and eggs.
Mr. T. Hodge Smith on September 11th, despite the severe inclemency of the weather, lectured to a large and appreciative audience on "Nature, the Master Sculptor." The lecturer outlined the various forces of nature and the parts they play in sculpturing the earth's surface. The action of rivers in channelling plains and forming mountains, dissolving rocks and forming caves, was described in detail - the Blue Mountains and Jenolan Caves being taken as instances. Glaciers also play an important part, and, though to day we have none in Australia, yet we have evidence of glacial action in times gone by.

In addition to these lectures various members of the Museum staff have lectured to large audiences at various centres. Mr. Kinghorn on August 13th spoke to the mem. bers of the Turramurra Community League, and again on the 28th to the members of the Teacher's Federation Horticultural Society and Gould League. On both occasions the lecturer stressed the value of birds to man and made a strong plea for their preservation, for, though laws may be made for the protection of wild life, they are of little worth unless the community is solidly behind them. Mr. A. Musgrave on 7 th August addressed the members of the Epping Congregational Young Mens' Club upon "Ants and Ant Communities," and on 8th September, lectured to members of the Bondi Methodist Church on "Lord Howe Island, the Madeira of the Pacific."

Leetures yet to be delivered are as follows, time of delivery, 8 p.m. :--

October 9th.-The Beginnings of Life. E. A. Briggs, M.Se.

October 23rd.-Conquering the Cannibal. E. A. Briggs, M.Se.

November 13th.-Non-Marsupial Mammals of Australia. E. Le G. Troughton.

December 11th.-Cave Land. Dr. C. Anderson. 


\title{
Snakes.
}

\section{THEIR FANGS AND VENOM APPARATUS. THE ACTION OF VENOM AND THE TREATMENT OF SNAKE-BITE.}

\author{
By J. R. Kinghorn, C.M.Z.S.
}

This contribution originally appeared in the first issue of The Australtan Museum Magazine. Frequent requests for information on this subject, and the issue containing it having long since been out of print, it is republished in a slightly amended form.-EDiTon.

$V^{\mathrm{s}}$

ENOMOUS snakes are divided into two large groups : those having fangs situated in the front of the jaw, and others that carry them towards the rear of the jaw. The second group need not concern us very much, but I might say before passing that their fangs are never hollow, but are always grooved. A typical representative in Australia is the Brown Tree Snake, which is absolutely harmless to man or any of the larger animals.

The first group concerns us most as the majority of our Australian venomous snakes belong to it, as do the cobras and krait of India, and the rattle snakes and vipers. The poison fang is a pointed, very sharp, recurved tooth, bearing along its length either a groove or a canal, ending a short distance from the point.

Australian venomous snakes have either grooved or hollow fangs which are permanently erect. The vipers and rattle snakes have enormously developed fangs attached to movable bones so that they may be automatically erected and depressed as the jaws open and shut; these fangs are almost perfect in structure, and may be likened to a hypodermic needle, as the edges of the groove are so flattened against each other that there is no trace of the join on the surface. As venomous snakes depend entirely upon their fangs in killing their prey they would naturally suffer considerable inconvenience if they were without them for any length of time through loss, so Nature has made ample provision in the great majority of cases by arranging reinforcements in the form of series of successively paired fangs which grow in the gums, and are in various stages of development, the most advanced pair being in a socket beside those in use and becoming solidly fixed and attached to the venom apparatus as soon as the old ones are lost.
The venom of snakes, and the apparatus by which it is injected, are subjects which have been extensively investigated by scientists. The venom glands of snakes are situated under the eyes, and each gland is enclosed in a dense fibrous sheath which is surrounded by the main muscles of the jaw. From each gland there is a duct, or tube,

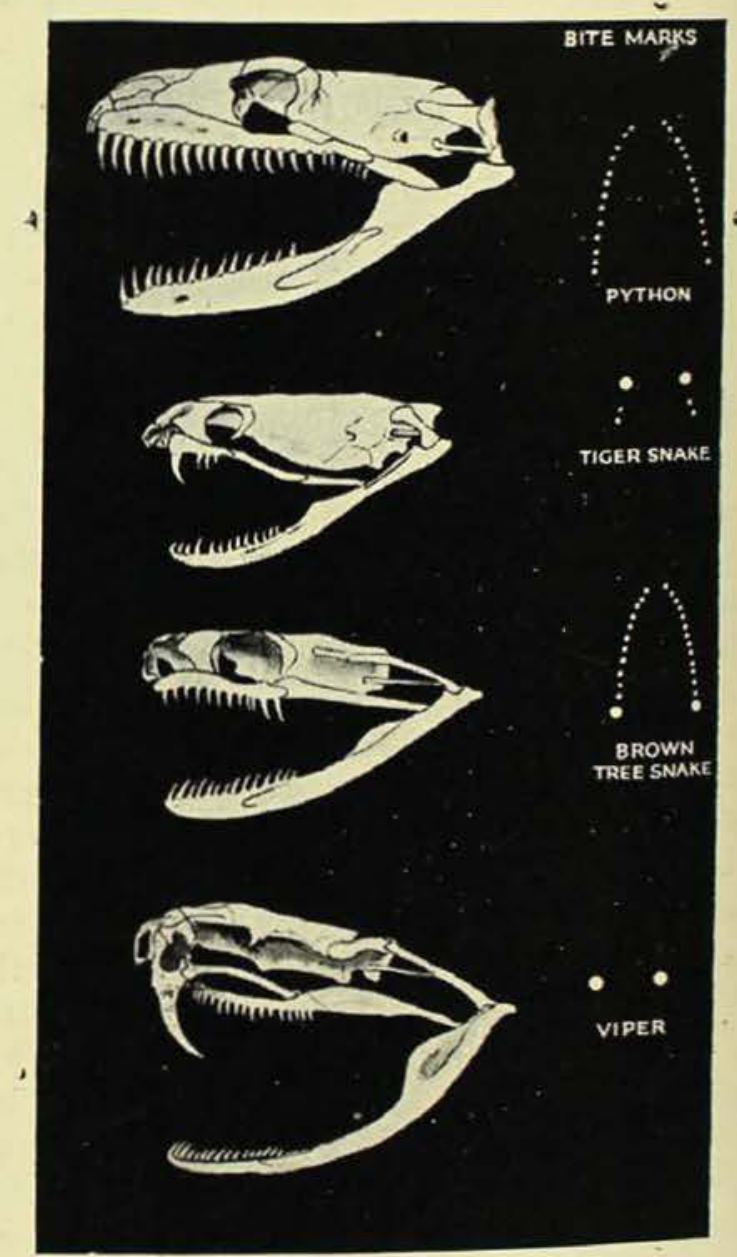

Skulls of Snakes showing bite marks. At the top is a Python skull (such as Carpet or Diamond snake, which are non-venomous, all the teeth being solid). Next is a Tiger or Black snake, and at the bottom a Viper, all of which are venomous. The Brown Tree Snake with fangs at the rear of the jaw is only slightly venomous. 


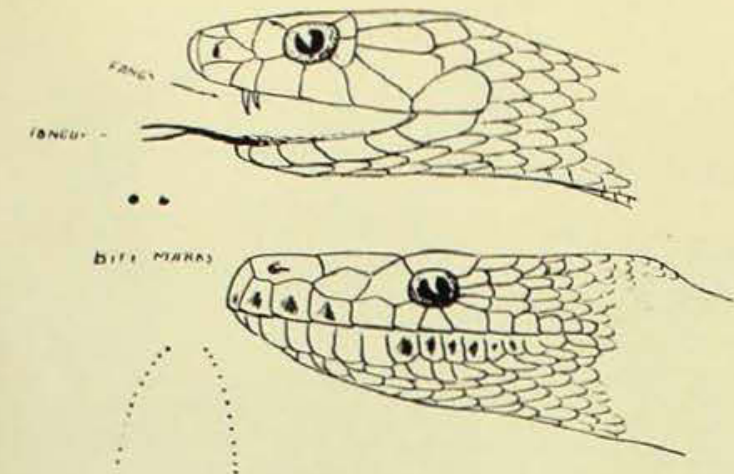

Bite marks of venomous snake above and Python (non-venomous (below).

which extends forward, terminating over the entrance to the canal or groove in the fang. The harder a snake bites the harder the tube is pressed against the canal in the fang, thus preventing any escape of venom other than through the canal or groove.

Venom can be ejected by some of the cobras in another manner than that of biting, the process being known as spitting. Observation has shown that venom is evidently forced into the mouth and mixed with the saliva, then it is ejected through the lips to a distance of six or eight feet. Several people have been temporarily blinded through its entering their eyes and causing severe inflammation.

Study and investigation has shown that most snakes possess certain glands which supply their blood with substances antagonistic to venom to render them immune to their own poison and often to that of other snakes.

Although the actions and symptoms which follow the bites of different snakes appear to be identical, it has been found that a serum which brings about immunity against one species has proved a failure in cases of bites caused by other species. Serum prepared for use against the cobra poison has proved futile against that of other species, and the same is perhaps the case between any two species of snakes throughout the world. Many instances, of which the following are several, might be given to prove this. A man who was well known around Sydney went to India, taking with him an antidote which he had used successfully against the venoms of Australian snakes. $\mathrm{He}$ was of the opinion that this same antidote would secure immunity from the poisons of the Indian species.
He was bitten by a krait, however, the venom of which acted upon his blood and nervous systems in a manner so different to what he had been used to in Australia, that the antidote failed to take effect, and he died. Another man who had become immune to the poison of the tiger snake was bitten by a copper-head or superb snake, and the bite proved fatal. Others who have become immune to the venom of vipers have died when bitten by cobras.

The immunity of the Indian snake charmer is brought about by his having submitted himself to a graduated series of injections of the venom of the species of snake with which he intends to play; this process of inoculation takes a considerable time to mature before the man becomes quite immune, and it is not without its risks.

Recent investigation has shown that the venom of the cobras, sea snakes, and our Australian species acts mainly upon the nerve centres which control the heart and respiration, eventually bringing about respiratory paralysis. At the same time, however, there may also be a clotting of the blood, but in the vipers and rattle snakes this effect seems to be reversed, the main action being the clotting of the blood. Doctors Fayrer and Brunton, two famous workers on snake venoms, hold the opinion that no special law can be laid down relating to the effect of venom, as it is dependent upon the species, state, and the size of the snake, the quality and quantity of its poison, and the circumstances under which it inflicts the bite; secondly, the species, size and vigour of the victim, and the circumstances under which it is bitten.

In India in 1911 there were over 24,000 lives lost through snake bite, but when the size of the population is taken into account, together with the fact that the majority of the people go about in the bush and jungle barefooted, it is a wonder there are not many more deaths from bites than the number stated.

Throughout the world there are many medical men who are making investigations and experiments with venoms with the object of finding an absolute antidote, one that will act successfully against poisoning and death from snake bite, no matter what species of snake inflicts the bite. A vast amount 


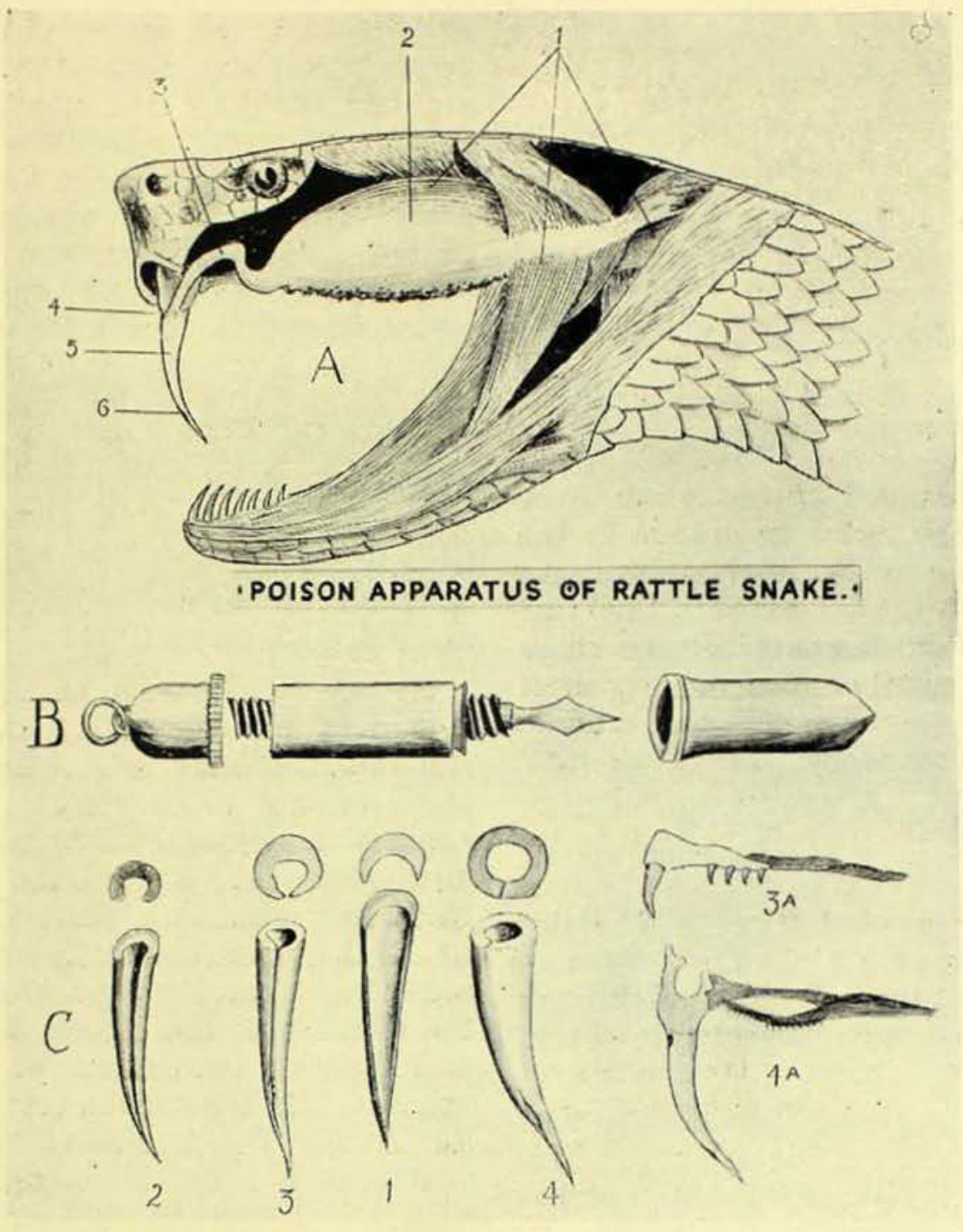

The venom apparatus of a snake consists of a pair of hollow or grooved fangs, situated one on each side of the upper jaw, generally at the front of the maxillary bone. To each of the fangs is attached a tube and a venom gland, the latter lying along the upper jaw, just under or behind the eve. When a snake bites, the muscles which surround the gland squeeze out the venom, force it along the tube and into the hollow fang, through which it passes, eventually finding its way out through an opening near the point, which may be buried deep in the lesh of a victim.

On the diagram there will be seen the poison apparatus of a rattle snake, and for convenience this may be considered typical of Australian venomous snakes, except that the fangs of our species are very much smaller and are permanently erect. The illustration shows the apparatus of one side of the head only.

A. (1) Muscles which open and close the jaws, surround the venom gland and squeeze out the venom.
(2) Venom gland, situated in a dense sheath of fibrous muscle. (3) Duet or tube, along which the venom is forced to the entrance of the canal in the fang. (4) Entrance to the canal in the fang. (5) Hollow fang. (6) Opening through which the venom leaves the fang.

B. Brunton's first-aid instrument for snake-bite, consisting of a lance, a screw cap cover, and a hollow handle which contains crystals of permanganate of potash.

C. (1) Ordinary grooved tooth possessed by many snakes in addition to the fangs. (2) Grooved fang as in the back-fanged snakes. (3) and (3a) Typical fang of Australian species, or the cobras, etc., in which the groove is not quite closed; this type of fang is generally followed by one or more small teeth. (4) and (4a) Typical hollow fang possessed by vipers and rattle snakes, the groove is completely closed : there are no other teeth on the maxillary bone, and it is erected or depressed as the jaws open and shut. 


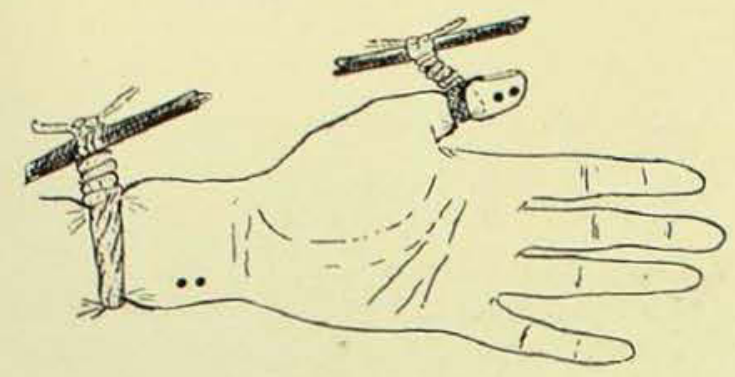

Ligatures tied to prevent snake poison spreading through the blood to the heart. The dots represent bite marks.

of valuable information has been supplied during the last few years.

In Australia the most dreaded species of snake is the death adder, and rightly too, for over 50 per cent. of persons bitten by this snake succumb to the venom. The tiger snake comes next with 45 per cent. deaths to bites inflicted; while the brown snake is much less deadly, the percentage of deaths from its bites being about eighteen. The black snake has very few deaths recorded against it at all, although the majority of bites are from this species.

In this country a fair number of fatalities from "snake bite" occur every year ; in many cases lives which have been lost could have been saved if proper treatment had been given. Some of the improper treatments one hears of, however, such as chopping off a finger or a toe, cutting out lumps of flesh, knocking a patient about to keep him awake, and other equally harsh operations, are absolutely unnecessary and often dangerous, and my effort here is to save all this as well as a few lives, by giving a safe and sure remedy, one that is within the reach of all, and if carried out quickly and correctly, should never fail in cases of bites from any of our Australian snakes.

Anyone who is likely to come in contact with venomous snakes, or any home situated near where these reptiles abound, should have the following essentials: (1) erystals of permanganate of potash, (2) a small, sharp knife or lance (3) and some string, elastic or rag that can be used as a ligature.

Following upon a bite from a venomous snake, and within a minute, if possible, a ligature must be applied close above the punctures, and on the side nearest the heart. Insert a stick into the loop of the ligature and twist it round until the latter is exceptionally tight; this is painful, but necessary. Then tie the stick higher up to prevent it unwinding. As soon as this is done wipe away any venom or saliva that may be on the surface of the skin, and make several longitudinal cuts over the fang punctures ; they should be as deep as or deeper than the punctures inflicted by the snake. Into these cuts force some crystals of permanganate, and then squeeze the wound so as to get rid of as much of the poisoned blood as possible. If there are no cuts, cracks or abrasions on the lips or in the mouth, the wound may be safely sucked, either by the patient or a friend; if any of the venom is accidently swallowed, no harm will come of it as long as the stomach is healthy and free from ulcers or inflammation. If the bites are on any part of the body where a ligature cannot be applied, as much of the above treatment as possible must be faithfully adhered to. As soon as these operations have been carried out a doctor should be sent for, but if they have been performed quickly and thoroughly, there need be very little anxiety as to the result, since permanganate of potash has been proved to be an absolute antidote to snake venom once it comes in contact with it. If a ligature be kept tight for more than half an hour there is danger of mortification setting in, so at the end of that time it should be loosened for an instant, and then tightened again. This operation should be repeated every five minutes, and the doctor will advise as to when the ligature may be finally removed. Should no doctor be available, then the loosening and re-tying of the ligature every five minutes may be carried on for at least another half hour.

Some writers have advised that if the bite is anywhere on the forearm or wrist, the ligature must be placed above the elbow, as there is only one bone there, and more pressure ean be brought to bear upon the blood vessels, but, as venom spreads exceptionally quickly, it is advisable to have it tied close to the wound so that the poisoning will be localised, and the venom can be removed more easily than if it were allowed to spread throughout the muscles. A second ligature may be placed above the elbow if desired, but it is not absolutely essential.

Alcohol and ammonia have no curative effect whatever, either taken inwardly or 
applied to the wound. Venom has been mixed with both the above and when injected has retained all its poisonous properties.

In some countries, especially where cobras and vipers exist, antivenine serum is procurable. This is injected hypodermically near the site of a bite, and has proved to be most effective. It is prepared by treating an animal (usually a horse) with increasing doses of venom for a considerable time, until it becomes immune to almost any amount of venom that may be injected into it; then the serum is extracted. It is effective in cases of bites from the species of snakes used in its preparation, but not in those in which the victim has been bitten by some other species; for instance, cobra antivenine is an antidote to cobra poison only. Some years ago the Public Health Department of New South Wales made a number of experiments by treating a horse with the venom of a tiger snake; eventually an antivenine serum was prepared and was effective, but only for bites inflicted by tiger snakes. In 1906 the same department issued a pamphlet on venoms, compiled by the doctor who made all the experiments, and I have no doubt that any student who is interested may still be able to procure one on application to the authorities concerned. There are many other splendid papers on snake venoms, antidotes, treatment, etc., but they mostly deal with snakes which are foreign to Australia. The following is a summary of the treatment, in the order in which it is best to apply it :-

1. Ligature: to localise the effect of poisoning.

2. Cut the flesh: to drain away poisoned blood.
3. Apply permanganate crystals: to neutralise and kill the venom.

4. Suck or squeeze out as much blood as possible.

5. Send for a doctor.

I have placed the doctor last on the list for the reason that every second is valuable; and every second that treatment is delayed means that the venom is getting a better hold upon the system. If the patient shows signs of collapse, give stimulants such as small doses of brandy or whisky, etc., or strong tea and coffee; he must also have complete rest.

Unless one has made a close study of snakes it would be almost impossible for him to determine at a glance a venomous from a non-venomous species, but the bite marks of the two types differ considerably from each other, as illustrated on page 143.

In Australia there are only two well known non-venomous snakes, and they are the diamond and carpet snakes ; so, for safety's sake, all other species had better be looked upon as deadly, or at least venomous. Any Australian snake which is not thicker than your little finger is too small to inflict a fatal bite.

It is as well, however, to treat all bites as dangerous, because in some cases, where the bite is from a non-venomous type, blood poisoning may set in.

In cases where the large number of punctures leaves no doubt as to the bite being that of a non-venomous snake, it is not necessary to apply a ligature or to cut the flesh, but the wound should be washed in a weak solution of permanganate of potash: and hot fomentations would be of great value.
This Magazine was founded with the object of bringing before the public the wealth of interest displayed in the galleries. To ourselves it has been very evident that the object has been achieved-old subscribers bring new subscribers and new subscribers frequently want back issues, some of which are out of print. Recently an advertising constituent told us that, due to our journal, he had extended his business to New Zealand. This is particularly gratifying to us. It shows clearly that the Australian Museum Maga. ZINE, whilst intended primarily for the public of New South Wales, is considered good reading outside the Commonwealth and is retained for future reading, not relegated to the waste paper basket. 